\title{
Artigo
}

\section{(Des)construção da gestão ambiental no Brasil: De Paulo Nogueira Neto (1973)} a Ricardo Salles (2020)

\author{
Paulo Pereira de Gusmão \\ Bianca Borges Medeiros Pavão
}

\begin{abstract}
Resumo
Este texto é composto por duas partes principais. Na primeira, destacam-se algumas das passagens mais importantes da construção de um sistema brasileiro de gestão ambiental. Esse processo construtivo (1973-2010) esteve, nos doze anos iniciais, em grande parte associado à figura de Paulo Nogueira Neto, responsável pela condução da primeira agência ambiental federal. Com base nesses elementos, formulase uma linha do tempo desdobrada em fases. Na segunda parte, analisam-se as mudanças normativas introduzidas no sistema na década 2010-2020, e sobretudo no último biênio desta. Essa análise evidencia uma ruptura e, consequentemente, a crise de desempenho e credibilidade do sistema brasileiro de gestão ambiental. Essa ruptura marca, assim, a contraposição entre dois "modelos": o que foi construído ao longo do período 1970/2010 e o segundo que resulta da sua desconstrução, que tem na promulgação do novo Código Florestal (Lei $n^{\circ} 12.651 / 2012$ ) um dos seus marcos mais importantes. Essa evidente bipolaridade é resultado de uma conjuntura própria da década 2010-2020, dentro da qual destaca-se o papel, a intencionalidade e a sistematicidade das ações levadas a cabo nos primeiros vinte meses do atual governo federal.
\end{abstract}

Palavras-chave: Ecologia Política; gestão ambiental; políticas ambientais; processo de desconstrução; Amazônia brasileira. 


\title{
(De)construction of the environmental management in Brazil: From Paulo Nogueira Neto (1973) to Ricardo Salles (2019)
}

\begin{abstract}
This paper is written in two main parts. At the first one, some of the most important aspects of the making of one Brazilian system of environmental management are highlighted. In this first part (1973-2010) is also highlighted the contribution of Paulo Nogueira Neto, head of the first environmental federal agency in Brazil and accountable for its development in the first twelve years. Based on these elements was built a timeline divided into phases. At the second part, the subject is enhanced by the analysis of the legal changes introduced in the system in the decades of 2010-2020, mainly in the last two years. It is then uncovered a disruption and, therefore, a crisis in the performance and reliability of the Brazilian system of environmental resource management. This split identifies the transition between two different patterns: one that had been shaped over the years of 1970-2010, and another that arises from its dismantling whose beginning is temporally related to the promulgation of the new Brazilian Forest Code (Law no.12,651/2012). This clear bipolarity derives from a particular context proper to the decade of 20102020, within which are underlined the role, the intention and the systemic nature of the actions undertaken in the first twenty months of the present federal government.
\end{abstract}

Keywords: Political Ecology; environmental resource management; environmental policy; dismantling process; Brazilian Amazon Rainforest.

\section{(Des)construcción de la gestión ambiental en Brasil: De Paulo Nogueira Neto (1973) a Ricardo Salles (2019)}

\begin{abstract}
Resumen
Este artículo consta de dos partes principales. En la primera, se destacan algunos de los pasajes más importantes de la construcción de un sistema brasilero de gestión ambiental. Esta primera parte (1973-2010) estuvo marcado por el liderazgo de Paulo Nogueira Neto en los doce primeros años. A partir de estos elementos, se produce una línea de tiempo que es desdoblada en fases. En la segunda parte, se analiza de modo más detenido los cambios normativos introducidos en el sistema en la década 2010-2020, en especial en el último bienio de esta. Se evidencia entonces una ruptura y, a continuación, una crisis del desempeño y credibilidad del sistema brasilero de gestión ambiental. Este momento de ruptura es el marco de una transición entre dos "modelos"; el que fue construido a lo largo del período 1970/2010 y el segundo que resulta de su deconstrucción. Esta evidente bipolaridad resulta de una coyuntura propia de la década 2010-2020, de la cual se destacan el rol, la intencionalidad y la sistematicidad de las acciones desarrolladas en los primeros 20 meses del actual gobierno federal.
\end{abstract}

Palabras clave: Ecología Política; gestión ambiental; políticas ambientales; proceso de desconstrucción; Amazonia brasileña. 


\section{Apresentação}

Ao longo do período 1970-2010, foram sendo acumulados avanços no desenho e experimentação de instrumentos de planejamento e gestão ambiental no contexto brasileiro (normas legais, aparatos institucionais, equipes técnicas etc.). O propósito, nem sempre bem-sucedido, era o de direcionar o uso da base de recursos pelas atividades modificadoras do ambiente, assim como definir e proteger remanescentes dos biomas brasileiros.

É imperioso observar que a parte inicial desse trabalho (referente às décadas de 1970/1980), liderado de 1973 a 1985 por Paulo Nogueira Neto, coincidiu com a transição entre um regime autoritário de exceção e o Estado de Direito Democrático. Apesar das dificuldades inerentes à conjuntura da época, datam desse período avanços em cinco direções principais que culminam na forma como a questão ambiental é tratada no Capítulo VI, Artigo 225 da Constituição Federal de 1988: (i) institucional: a construção de aparatos técnico-administrativos estaduais e nacional, assim como de normas e padrões (principalmente no que se refere ao "controle da poluição") configurando um modelo de comando e controle; (ii) qualidade ambiental: desenvolvimento de procedimentos e mecanismos de monitoramento-controle da poluição do ar e das águas, temas esses focados inicialmente nas regiões metropolitanas e algumas bacias (hídricas e aéreas) já então submetidas a pressões antrópicas importantes; (iii) espaço-tempo dos conflitos gerados por grandes empreendimentos: instituição da Licença Ambiental e da Avaliação de Impactos Ambientais como requisito no caso dos projetos com significativo potencial de transformação ambiental; (iv) gestão pública coordenada/cooperativa: criação do Sistema Nacional de Meio Ambiente (SISNAMA) e do Conselho Nacional do Meio Ambiente (CONAMA), assim como da consolidação de outros conceitos e instrumentos previstos na Política Nacional de Meio Ambiente instituída pela Lei nº 6.938/81; e (v) conservaçãopreservação ambiental: o incremento de espaços legalmente protegidos (sobretudo unidades de conservação, terras indígenas e quilombolas) visando a preservação de habitats 
naturais e formas de vida tradicionais. Não restam dúvidas sobre a contribuição de Paulo Nogueira Neto para se chegar a esses avanços. Sobretudo se considerarmos que a liderança desse processo de construção se deu ainda durante o Regime Militar, sob a égide dos Planos Nacionais de Desenvolvimento (PNDs) e do forte discurso associado ao chamado milagre brasileiro.

Pulando de um extremo ao outro, verifica-se na década 2010/2020, na vigência de um Estado de Direito Democrático tido como consolidado, que o sistema brasileiro de gestão ambiental' , construído ao longo de quatro décadas de ensaios e erros, assim como de avanços e retrocessos, passa a estar submetido a uma pressão revisionista que aponta para sua profunda descaracterização. Em relação à essa pressão revisionista destacamos, no início da década, o novo Código Florestal promulgado em 2012 e, no outro extremo, as iniciativas que vem sendo conduzidas desde 2019 no âmbito do Governo Bolsonaro. Não que ele tenha sido necessariamente o mentor de todas essas iniciativas, pois talvez Ihe tenha cabido apenas o papel de operador das iniciativas sistemáticas, coordenadas e intencionais de desmonte do sistema ambiental a nível federal, planejadas como parte de um projeto de governo como mais adiante analisamos.

Por se tratar de um período bastante dinâmico, complexo e repleto de divergências e conflitos - natural em qualquer processo de construção e consolidação de políticas públicas -, optamos por organizar o texto com ênfase em fases, embora não esgotem todos os acontecimentos verificados em cada período. Para isso, incorremos - certamente - em simplificações e generalizações inevitáveis face às dimensões próprias de um artigo cujo objetivo principal é o de possibilitar ao leitor uma visão panorâmica das políticas ambientais consolidadas ao longo de quase meio século, marcando alguns pontos de convergência e de inflexão identificados.

Diante da lacuna identificada por Souza (2020) quanto à carência de textos de referência sobre a Ecologia Política - especialmente escritos em língua portuguesa e que

\footnotetext{
1 Entendido como o conjunto de normas, instrumentos, instituições e instâncias deliberativas que estruturam, orientam e materializam a forma como as políticas ambientais brasileiras são formuladas e conduzidas.
} 
encontrem raízes na Geografia -, esperamos que o presente texto, a partir da proposta de análise crítica do sistema brasileiro de gestão ambiental apresentada, possa a vir a contribuir fertilizando novas reflexões neste campo, voltadas para a realidade brasileira, ainda que não tenha sido nossa pretensão realizar uma revisão sistemática da literatura que discute as relações entre ambientes e territórios.

A trajetória dessa construção das políticas ambientais brasileiras foi recuperada a partir da consulta ao material bibliográfico já produzido sobre o tema combinada à experiência pessoal dos autores. O processo de "desmonte" vem evoluindo de forma mais visível desde o início da década de 2010 - tendo na votação e promulgação do novo Código Florestal (2012) um de seus mais destacados "marcos legais" - ganhando velocidade, sistematicidade e coordenação desde 2019. Essa trajetória foi levantada a partir de consulta às várias mídias e aos atos normativos promulgados durante o período que vai de janeiro/2019 a março/2020.

O procedimento metodológico adotado envolveu o levantamento das Leis, Decretos, Leis Complementares, Medidas Provisórias e Projetos de Lei editados buscando identificar aquelas com aderência à matéria ambiental. Em caso positivo, analisamos com maior detalhamento a origem do ato, isto é, se advindo do poder legislativo ou executivo, o tema e a região que, porventura, receberia de forma mais direta os efeitos da nova norma. Na sequência, depois de indexadas, foram realizadas análises sobre as alterações provocadas pelas normas. Além das normas, também consistiu importante fonte para a realização do estudo, o documento organizado pela Associação Nacional dos Servidores de Meio Ambiente (ASCEMA, 2020) que reuniu, em ordem cronológica, notícias online veiculadas por diferentes fontes entre os anos 2018/2020 cuja temática estivesse relacionada às políticas ambientais brasileiras, tanto em termos de modificações, declarações e denúncias de eventuais irregularidades por parte dos analistas ambientais. 


\section{Introdução}

Pressões contra os avanços do sistema brasileiro de gestão ambiental sempre estiveram presentes nos discursos e ações de agentes e entidades que discordavam dos "constrangimentos" impostos aos seus interesses e atividades. Um comportamento nada surpreendente pois, de acordo com Rocco (2002), a legislação ambiental materializa, em resumo, uma nova ética social em dois sentidos principais: (i) o ser humano deixa de ser o centro do universo; e (ii) o meio ambiente passa a ser considerado um patrimônio coletivo, devendo o acesso aos recursos e à qualidade ambiental usufruída se dar de forma equânime pelos diferentes segmentos sociais. Assim, não deve causar espécie que surjam reações contrárias ao novo ordenamento que determina que o uso da propriedade deve "se adequar não apenas ao desejo de seu titular, mas também ao bem comum, visando impedir danos à coletividade e ao meio ambiente natural e construído". Por esse aspecto, o direito ambiental seria um "direito revolucionário" (ROCCO, 2002, p. 16).

É fato, pois, que críticas ao ordenamento jurídico-institucional sempre estiveram presentes, embora desprovidas, até poucos anos, da força e organização necessárias para alcançar seus objetivos. Nos últimos anos tais reações vêm ganhando maior visibilidade, projetando um cenário diverso daquele que sugere o ordenamento jurídico ainda predominante. Uma nova conjuntura (ou "onda conservadora") em nível nacional e internacional que passa a viabilizar retrocessos antes inadmissíveis.

As tentativas de flexibilização do processo de licenciamento ambiental iniciadas nos anos 2000, especialmente na aplicabilidade do instrumento de avaliação dos impactos de projetos com grande potencial transformador do território, representam alguns dos retrocessos recentes. Outras mudanças vêm sendo gradativamente introduzidas, como no sentido da flexibilização das políticas e normas ambientais, resultando no enfraquecimento da legislação ambiental e do marco institucional através do qual as políticas se materializam. A partir de 2018 as narrativas favoráveis à necessidade de "revisão" se 
tornam mais explícitas e sistemáticas, passando a envolver críticas explícitas sobre temas, tais como: recategorização e redução da área de Unidades de Conservação (sobretudo na Amazônia); regularização das atividades, sobretudo exploração mineral, em terras indígenas; regularização de terras ilegalmente ocupadas-desmatadas; e cancelamento de compromissos (inclusive a nível internacional) no campo da mitigação e adaptação às mudanças climáticas. Sem mencionar questões como a liberação da posse/porte de armas (assim como da compra de munição) e do licenciamento desmedido dos agrotóxicos produzidos e comercializados no país. Compõem também esse cenário as decisões que introduzem modificações radicais nas estruturas e funções de agências estatais como o Instituto Brasileiro do Meio Ambiente e dos Recursos Naturais Renováveis (IBAMA), o Instituto Chico Mendes de Conservação da Biodiversidade (ICMBio), a Fundação Nacional do Índio (FUNAI), o Conselho da Amazônia, envolvendo também a ressubordinação de outras tantos como no caso do Conselho Nacional de Recursos Hídricos (CNRH) e da Agência Nacional de Águas e Saneamento Básico (ANA). Nestes dois casos, antes situados na esfera do Ministério do Meio Ambiente (MMA), tais organizações, responsabilidades e equipes foram transferidas para a esfera do Ministério de Desenvolvimento Regional (MDR), para onde foram transferidas também pautas anteriormente abrigadas nos Ministérios das Cidades e de Integração Nacional. O mesmo MDR que batalha pela retomada de uma política desenvolvimentista calcada no planejamento de um novo período de grandes projetos. Nesse sentido, o MDR tem-se mostrado capaz de se opor à força da equipe econômica do atual governo e sua política fiscalista-privatista, embora isso não gere ganhos em favor do sistema de gestão ambiental ou da defesa do meio ambiente.

Despertaram também veementes críticas os efeitos introduzidos por decisões presidenciais, tais como as de que tratam o Decreto $n^{\circ} 9.759 / 2019^{2}$, que extinguiu colegiados federais, vários deles tratando de matérias de interesse ambiental, e o Decreto $\mathrm{n}^{\circ}$

\footnotetext{
${ }^{2}$ Este decreto foi contrariado por decisão liminar do Supremo Tribunal Federal (STF), de 13/06/2019, cabendo a ação ser julgada pelo plenário do STF em data a ser marcada.
} 
9.806/2019, que alterou a composição e, portanto, a representatividade da plenária do Conselho Nacional do Meio Ambiente (CONAMA). O alcance dessa recomposição ficou evidenciado recentemente ao serem revogadas as Resoluções 302 e 202 que versavam sobre a proteção das vegetações de restinga e de manguezal.

Em outro contexto a complexidade e importância de tais decisões demandariam uma avaliação cuidadosa das suas implicações, seja no que se refere às regiões/biomas afetados, dos agentes, setores e cadeias produtivas envolvidas, seus interesses e escalas de ação, assim como dos grupamentos sociais positiva ou negativamente afetados. Em sentido contrário, tais decisões têm sido gestadas de forma centralizada, quase monocrática. Ao que parece estaria à cidadania crer que uma combinação entre mobilização social, recursos endereçados ao sistema judiciário e, por outro lado, pressões impostas pela opinião pública internacional (incluindo aí poderosos grupos de investimento estrangeiros) poderiam vir a resultar em trincheiras de resistência que imponham limites a tal processo.

Como já dissemos, importa lembrar que muitas dessas medidas apontam em sentido radicalmente contrário aos princípios que nortearam, desde a década de 1970, a construção e consolidação do sistema brasileiro de gestão ambiental. Não se trata, portanto, de discutir sobre o mérito de pequenos ajustes ou aperfeiçoamentos, mas de mudanças na essência do sistema, tanto no que diz respeito à sua concepção, objetivos, estratégias e condições de operacionalidade. Várias dessas medidas conflitam com o que consagram diplomas legais basilares, tais como a Lei $n^{\circ}$ 6.938/1981, que instituiu a Política Nacional de Meio Ambiente (PNMA), e a própria Constituição Federal de 1988.

\section{Um pano de fundo: As responsabilidades dispersas e a gestão utilita- rista dos recursos ambientais anteriores à década de 1970}

Desde a década de 1930 até o início dos anos 1970, viveu-se um longo período em que as políticas ambientais obedeceram a uma estruturação incompleta e setorializada, 
assim como a um enfoque utilitarista. De um lado, as responsabilidades quanto ao controle do uso dos recursos estavam distribuídas entre vários organismos que não mantinham relações de cooperação e coordenação, materializando a compartimentação a que nos referimos. Por outro lado, o ambiente era visto como uma entidade fornecedora de insumos destinados a satisfazer às necessidades de um país que transitava do rural para o urbano, assim como de uma economia antes agrária e que dava os primeiros passos na direção da industrialização. A literatura a propósito destaca a presença dessas características nos códigos, elaborados ainda na década de 1930, que tratavam de disciplinar as pressões exercidas sobre os recursos hídricos, minerais e florestais. Outro avanço notável foi a criação do Parque Nacional de Itatiaia, em 1937, precursor de outras áreas protegidas (hoje classificadas como Unidades de Conservação) criadas pelas diferentes esferas governamentais, indicando os primeiros passos para a assimilação de valores afeitos à preservação ambiental.

Na década de 1960, a cultura ambiental brasileira refletia ainda essa visão utilitarista dos recursos e a consequente setorialização da ação pública no trato das diferentes matérias que compõem a agenda ambiental brasileira. Essas ênfases foram sendo retrabalhadas como ficou evidenciado no novo códigos florestal editado em 1965, assim como foram sendo viabilizadas a partir da ação de novas organizações, tais como o Instituto Brasileiro de Desenvolvimento Florestal (IBDF), criado em 1967, a Superintendência de Desenvolvimento da Pesca (SUDEPE), também criada em 1967, e o Departamento Nacional de Obras Contra a Seca (DNOCS), criado em $1963^{3}$.

No que diz respeito à presença de organizações da sociedade civil no Brasil, cabe destacar a Fundação Brasileira para a Conservação da Natureza (FBCN), criada em 1958, uma das mais destacadas ONGs ambientalistas brasileiras até o final da década de 1960 (FRANCO; DRUMMOND, 2009). As ligações entre seus membros e algumas instituições

\footnotetext{
${ }^{3}$ Criado sob o nome de Inspetoria de Obras Contra as Secas (IOCS), por meio do Decreto n ${ }^{\circ} 7.619 / 1909$, o DNOCS foi o primeiro órgão a estudar a problemática do semiárido. O então IOCS foi transformado em Inspetoria Federal de Obras Contra as Secas (IFOCS), pelo Decreto n 13.687/1919, para só assumir sua denominação atual em 1945 (Decreto-Lei $n^{\circ} 8.486$, de 28/12/1945). Finalmente, o DNOCS foi transformado em autarquia federal, por meio da Lei $n^{\circ}$ 4.229, de 01/06/1963. Fonte: <https://www2.dnocs.gov.br/historia>. Acesso em 25/04/2020.
} 
governamentais possibilitou à $\mathrm{FBCN}$ apoiar, dentre outras, a formulação das políticas públicas a propósito da criação e regulamentação de parques nacionais, assim como do anteprojeto do Código Florestal de 1965.

Desde a década de 1960, a Amazônia passou a ocupar lugar de destaque na agenda ambiental brasileira. Não que a região (ou o bioma) tivessem sido ignorados em tempos anteriores. Contudo, foi nessa década que começaram a surgir reações a conflitos relacionados ao acesso/uso de seus recursos, destacando-se a criação da Campanha Nacional de Defesa e Desenvolvimento da Amazônia (CNDDA, 1967), liderada pelo Geógrafo Orlando Valverde. A criação da CNDDA pode ser interpretada como uma resposta a projetos de "desenvolvimento" da região, dentre os quais ganhou destaque o projeto dos Grandes Lagos Amazônicos, desenvolvido pelo Hudson Institute, sob a condução de Hermann Kahn (KOHLHEPP, 2015).

\section{Uma linha do tempo das políticas ambientais brasileiras no período} $1970-2020$

Exercícios de periodização envolvem questões delicadas, sobretudo quando tratamos de um intervalo de tempo tão longo quanto denso (1970-2020). Dentre outras razões nos preocupou a necessidade de fazer "escolhas de Sofia" que nos levariam a simplificações e generalizações, as quais seriam agravadas pelas múltiplas diversidades de um país com as dimensões do Brasil. Reforça essa preocupação o fato de, tanto no plano nacional como internacional, o período a que nos referimos ter sido dos mais complexos, dinâmicos e intensos da história. Por outro lado, é fato que as políticas públicas não se sucedem mecanicamente, já que não são substituídas umas pelas outras de forma linear. Os fatos/eventos, composições de forças e efeitos gerados podem permanecer em espaços e tempos diferenciados, sobrepondo-se muitas vezes, combinando umas e outras de formas sinérgicas e cumulativas razoavelmente imprevisíveis, permanecendo ou sucedendo 
de forma aparentemente "desorganizada”. Nesses casos, o difícil não é só entender qual a ordem das coisas e dos fatos, mas sobretudo entender por completo quem está no controle, quais os agentes e alianças determinantes e quais interesses (ou combinação deles) foram ou serão privilegiados.

Como ver-se-á mais adiante, a trajetória que apuramos não conflita outras como aquela sugerida por Benjamim (apud ROCCO, 2002, p.17) sobre a evolução da proteção jurídica do meio ambiente no Brasil. Também não divergiremos das linhas gerais estabelecidas por Ferreira e Salles (2016), Moura (2016), Bursztyn e Brusztyn (2012), Drummond e Barros-Platiau (2006) e Coelho e Cunha (2003) em seus trabalhos sobre a trajetória das políticas ambientais no mesmo período. Por outro lado, não foi nossa intenção compor uma abordagem semelhante àquela realizada por Jasso (2019), cujo intuito foi de recuperar a epistemologia da história ambiental brasileira.

Por se tratar de uma linha do tempo que privilegia certas ênfases e acontecimentos, algumas (talvez muitas?) "escolhas de Sofia” foram feitas, como já mencionamos. Isso poderá desagradar ou frustrar alguns leitores. Uma dessas escolhas diz respeito ao fato de considerarmos que a Amazônia foi, dentre os biomas brasileiros, o alvo preferencial das investidas feitas em favor da sua proteção, assim como, recentemente, da reversão do arcabouço político-institucional-legal construído no período 1970-2010. Sendo assim, embora trabalhemos sobre a ideia da construção de um sistema brasileiro de gestão ambiental, o bioma Amazônia servirá como uma espécie de eixo referencial das reflexões aqui relatadas. Efetivamente, a análise mais adiante apresentada sobre mudanças normativas realizadas no atual governo Bolsonaro comprova que as polêmicas medidas tomadas a partir do Governo Bolsonaro (especialmente na esfera do MMA, sob a administração de Ricardo Salles) tem na Amazônia seu objeto principal de intervenção. 


\section{1. "Milagre brasileiro", pressões externas, institucionalização da gestão ambi- ental e redemocratização}

O Regime Militar, instalado no país em 1964, teve no afã de promover o desenvolvimentismo que inspirava o "milagre brasileiro", um olhar peculiar para as questões ambientais e, particularmente, para a Amazônia. Desse olhar fizeram parte políticas oficiais como as que deram origem à Operação Amazônia (1970), ao Programa de Integração Nacional (PIN, 1970) e ao Programa de Polos Agropecuários e Agrominerais da Amazônia (POLOAMAZONIA, 1974) que integravam os esforços estratégicos visando "integrar para não entregar"'. Como assinalado por Kohlhepp $(2020)^{5}$, a questão ambiental integrava, sobretudo no caso da Amazônia, a agenda do Conselho de Segurança Nacional mais que, como poderia ser imaginado, do então Ministério do Interior.

Por outro lado, os anos 1970 foram marcados pelas pressões exercidas sobre o governo brasileiro por fóruns internacionais e organismos multilaterais, assim como por nações estrangeiras de forma isolada. A Conferência das Nações Unidas sobre o Meio Ambiente Humano (Estocolmo, 1972) - respaldado no relatório Limites do Crescimento (1972) elaborado pelo Massachusetts Institute of Technology (MIT) por solicitação do Clube de Roma (criado em 1968) - representa uma das referências obrigatórias desse período. Importante assinalar que tais pressões externas (envolvendo não só questões ecológicas, mas também em favor do encerramento do período autoritário instalado em 1964) geraram como que alianças implícitas que deram sustentação ao atendimento de algumas expectativas da sociedade brasileira à época. É bem possível que, de outra forma, as reivin-

\footnotetext{
${ }^{4}$ Como parte de uma resposta às pressões pela internacionalização da Amazônia, o PIN tinha como objetivo a implementação de obras de infraestrutura, especialmente no Norte e Nordeste do país, dentre as quais vale destacar as rodovias Tranzamazônica e Cuiabá-Santarém que amparavam projetos de colonização, agropecuários e agroindustriais.

${ }^{5}$ Ver entrevista neste mesmo número de AMBIENTES.
} 
dicações de ordem social e política, assim como aquelas formuladas pelo incipiente movimento ambientalista brasileiro, não tivessem logrado os resultados obtidos, pelo menos nos prazos em que eles se deram.

Os movimentos visando à criação de um aparato institucional-legal para a gestão ambiental do território brasileiro precederam o início de uma contagem regressiva do processo de redemocratização e descentralização político-administrativa do país verificada ao final dessa década. A Lei da Anistia (1979), responsável pelo retorno de exilados políticos, alguns deles ex-líderes dos movimentos estudantis e que se tornariam importantes lideranças ambientalistas ${ }^{6}$

Vale lembrar que a vida política no país passou na década de 1970 por um momento de reorganização e fortalecimento de suas bases, abrindo espaços para o debate social em égides mais plurais e integradas, de forma que envolviam questões tais como qualidade de vida, saneamento e poluição nas cidades, preservação ambiental e desenvolvimento rural, dentre outras. A multiplicação das associações civis ganha uma crescente visibilidade e peso que vão ser consolidados na década de 1980, quando então já se contava com uma rede nacional articulada a organizações, sobretudo sociais, sindicais e políticas. O fato de a agenda ambiental brasileira integrar um vasto espectro de questões (associadas às áreas urbanas, agrárias, florestais etc.) potencializou a mobilização e diversidade das organizações sociais dedicadas a temas convergentes, tais como habitação, saneamento, poluição do ar e das águas, biodiversidade, contaminação de solos e aquíferos etc.

Em função de compromissos assumidos na Conferência de Estocolmo combinados às pressões que já exerciam agências (internacionais e multilaterais) de financiamento o Estado brasileiro deu os primeiros passos na direção da institucionalização do tema ambiental de forma mais sistêmica. Decorrida a primeira metade da década haviam sido criadas a Secretaria Especial do Meio Ambiente (SEMA, 1973), vinculada ao Ministério do

\footnotetext{
${ }^{6}$ A propósito, vale destacar o Partido Verde (1986) de cujo processo de criação tiveram participação destacada personagens como Herbert Daniel, Fernando Gabeira, Carlos Minc, Alfredo Sirkis, lideranças que regressaram ao país sob o amparo da Lei da Anistia (1979).
} 
Interior (MINTER), assim como as primeiras agências estaduais de meio ambiente. ${ }^{7}$ Há razões para dizermos que a experiência brasileira em matéria de gestão ambiental nasceu assim “desconcentrada” em função da destacada contribuição (mais técnica que política, é bem verdade) das agências ambientais estaduais. ${ }^{8}$

Como assinalado também por Kohlhepp (2020), a SEMA compreendia um arranjo institucional frágil, mas importante como núcleo de coordenação política de âmbito federal. Ela foi liderada pela figura emblemática de Paulo Nogueira Neto ${ }^{9}$ de 1973 a 1985. A propósito desse personagem, Kohlhepp (2020) comenta que ainda que as condições políticas fossem difíceis, ele foi responsável pela proposição de iniciativas que constituíram as bases para a reformulação da legislação ambiental nacional em 1981. A partir da sua criação, a SEMA cumpriu, com alguns outros méritos, o papel de condição necessária para que o país tivesse acesso aos recursos das agências multilaterais e estrangeiras para o financiamento de grandes projetos. Nessa condição, trabalhando muitas vezes por meio das "brechas possíveis", foram sendo viabilizados alguns avanços na temática ambiental, seja prevenindo "estragos maiores" ou fortalecendo a capacidade de resposta dos aparatos institucionais e legais ainda "em fase de construção".

Enquanto isso, às agências estaduais cabia o labor técnico de, sempre consultada a experiência internacional, desenvolver os instrumentos e práticas técnico-administrativas a serem aplicadas. Experimentou-se assim uma espécie de divisão nacional do trabaIho, cabendo a cada agência estadual o desenvolvimento do conhecimento na(s) área(s) que Ihes eram mais "familiares" ou "próximas", como por exemplo: (i) em São Paulo, onde já se lidava com graves problemas de poluição do ar, a Cetesb se transformou, à época, no centro de excelência nesse campo; (ii) no caso do Rio de Janeiro, que vivia de

\footnotetext{
7 Destaque especial para a Cetesb (SP) e a Feema (RJ) que formaram as primeiras equipes que, por algum tempo, apoiaram a constituição de agências congêneres em outros estados brasileiros.

${ }^{8}$ Contudo, avanços importantes em matéria de descentralização só aconteceram a partir de meados da década de 1980 quando as agências ambientais a nível municipal começaram a ser criadas. A precursora, nesse caso, foi a Secretaria de Meio Ambiente de Curitiba, criada em 1985. Contudo, somente na década de 1990, como decorrência do caráter descentralizador e municipalista da Constituição Federal de 1988, cresceu o número de municípios que passaram a dispor de uma agência própria para responder (ao menos formalmente) pela agenda ambiental.

9 Para os que queiram consultar uma introdução ao papel desempenhado por Paulo Nogueira Neto, sugerimos a leitura do Diário de uma trajetória ambientalista (São Paulo: Empresa das Artes, 2010), de P. Nogueira Neto.
} 
perto problemas de qualidade e disponibilidade hídrica, a Feema foi levada a desempenhar um papel de protagonismo nessa matéria; (iii) no Rio Grande do Sul, as ações da agência ambiental estadual, situada na esfera da Secretaria de Saúde e influenciada pela Associação Gaúcha de Proteção ao Ambiente Natural (AGAPAN, 1971) ${ }^{10}$, liderava nacionalmente os debates sobre o uso dos agrotóxicos. Pesaram a favor nesse período as práticas institucionalizadas de planejamento das cidades (médias, metrópoles e regiões metropolitanas) que se consolidara no país desde a década de 1960. Como sugerido por Ferreira e Salles (2016), importa destacar a ênfase dada no II Plano Nacional de Desenvolvimento (1974) à temática do desenvolvimento urbano e da poluição industrial, o que levou à definição das chamadas "áreas críticas de poluição" "e, posteriormente, à criação das regiões metropolitanas. As políticas a cargo de organizações tais como o Ministério do Interior (Minter), o Conselho Nacional de Política Urbana (CNPU), o Serviço Federal de Habitação e Urbanismo (SERFHAU), o Banco Nacional de Habitação (BNH) e a Caixa Econômica Federal (CEF) davam sustentação a ações de planejamento urbano e regional, com destaque para os Planos Diretores municipais e Planos de Desenvolvimento Local Integrado (PDLI), assim como dos Zoneamentos Industriais das Regiões Metropolitanas, os quais incorporavam, ainda que de forma incipiente, a dimensão ambiental.

Ainda sobre o planejamento e gestão dos territórios deve-se destacar as práticas voltadas para: (i) a definição, desde pelo menos a década de 1930, de espaços protegidos tais como os Parques Nacionais, Reservas Indígenas e figuras legais correlatas; e (ii) as políticas e ações relacionadas ao controle da poluição, sobretudo o caso dos Zoneamentos Industriais das Regiões Metropolitanas realizados na década de 1970.

Finalmente, merece destaque uma mudança de postura dos organismos de financiamento internacional, com destaque para o Banco Mundial (BM), como consequência das pressões que estes passavam a receber em decorrência dos projetos polêmicos que

\footnotetext{
${ }^{10}$ Liderada por ambientalistas pioneiros, dentre os quais José Lutzemberger, uma liderança polêmica e enérgica, reconhecida nacional e internacionalmente, que vinte anos depois, às vésperas da Conferência do Rio 92, veio a ocupar o cargo de Secretário do Meio Ambiente (SEMAM) da Presidência da República.

${ }^{11}$ Ver também Decreto-Lei no ${ }^{\circ}$ 1413/1975 que dispõe sobre o controle da poluição do meio ambiente provocada por atividades industriais.
} 
financiavam no Brasil e no mundo. Essa mudança fica mais clara na década de 1980, quando as operações de crédito passaram a estar condicionadas ao licenciamento ambiental prévio dos empreendimentos, para o que se tornara prática corrente a elaboração de Estudos de Impacto Ambiental (EIA). Contudo, nenhuma das mudanças assinaladas (sejam políticas, institucionais ou conceituais/metodológicas) tinham a força ou o propósito de introduzir mudanças substantivas no modelo desenvolvimentista vigente; o país seguia trilhando o caminho do crescimento econômico a qualquer custo. Aliás, a posição levada pela missão brasileira à Conferência de Estocolmo era a de que "a pior forma de poluição era a poluição da pobreza" e que a via do "desenvolvimento a baixo custo ecológico" representava uma possibilidade real.

\subsection{Política Nacional do Meio Ambiente (PNMA), sua regulamentação e a Consti- tuição Federal de 1988}

Desde a segunda metade da década de 1970, eram realizados ensaios com instrumentos orientados pela experiência internacional (sobretudo norte-americana e europeia), tais como as normas de controle da poluição, as licenças ambientais, os estudos prévios de impactos ambientais e a gestão das bacias hidrográficas ${ }^{12}$.

A definição mais clara de um sistema brasileiro de gestão ambiental acabou sendo estabelecida pela Lei da Política Nacional do Meio Ambiente - PNMA (Lei Federal $\mathrm{n}^{\circ}$ 6.938/1981) que ainda hoje, passados quase quarenta anos, se mostra bastante atual. Pode-se dizer que é a partir da PNMA que a política ambiental brasileira ganha uma arquitetura mais bem definida (BARROS et al., 2012). A criação do Sistema Nacional de Meio Ambiente (SISNAMA) e do Conselho Nacional do Meio Ambiente (CONAMA) merecem destaque. Por um lado, o SISNAMA foi importante como meio de mobilizar, apoiar e coordenar os esforços dos estados para a criação das suas respectivas agências e definição

\footnotetext{
${ }^{12}$ O Sistema de Licenciamento de Atividades Poluidoras (SLAP), instituído no âmbito do Estado do Rio de Janeiro pelo Decreto-Lei n ${ }^{\circ} 1.633 / 1977$, é um exemplo disso.
} 
de suas agendas ambientais. Por outro lado, os debates realizados pelo colegiado do CONAMA (através da sua plenária e suas Câmaras Técnicas) permitiram formalizar um amplo leque de normas para a estruturação e sustentação de ações cobrindo uma agenda tão ampla quanto diversa (BURSZTYN; BURSZTYN, 2012). A Resolução CONAMA 001/86, que regulamentou a figura da AIA prevista na Lei Federal n 6.938/81, representa também um marco importante no processo de construção desse sistema.

Vale sublinhar que o Licenciamento Ambiental, formalizado pela PNMA como instrumento mandatório a nível nacional, se transformou desde então (permanecendo parcialmente nessa mesma condição até hoje) no mais promissor instrumento técnico-administrativo de controle sócio-estatal do uso/ocupação territorial nas diferentes escalas. Outros procedimentos e instrumentos - como os alvarás municipais para localização de atividades e as licenças para a realização de obras - têm importância, porém numa perspectiva temático-espacial mais limitada. O licenciamento ambiental, sobretudo com a incorporação dos Estudos de Impacto Ambiental (na escala dos grandes projetos responsáveis por efeitos/impactos ambientais de caráter regional), passou a ser o mais poderoso (e, por isso, até hoje o mais combatido ${ }^{13}$ ) instrumento de controle territorial à disposição das diferentes esferas governamentais e da própria sociedade. Contudo, o uso desse instrumento tem dado lugar a muita insatisfação e frustração, pois são muitas as formas de burlar os propósitos originais do legislador em defesa do interesse coletivo. A incorporação dos procedimentos de Avaliação Ambiental Estratégica (AAE, numa escala macro) e dos Estudo de Impacto de Vizinhança (EIV, numa escala local ou do lugar) veio a complementar esse arranjo, embora não tenham ficados isentos dos mesmos "pecados" cometidos no caso dos EIA/RIMA.

Uma série de outros diplomas legais editados nesse período podem ser elencados como indicadores dos avanços obtidos em termos da regulação de diversas temáticas

\footnotetext{
${ }^{13}$ A esse respeito, podem ser citados: $\mathrm{PL} \mathrm{n}{ }^{\circ}$ 3.729/2004; PEC n ${ }^{\circ}$ 65/2012; PL n ${ }^{\circ}$ 602/2015; PL n ${ }^{\circ}$ 168/2018, cujos objetivos convergiram em direção à flexibilização do funcionamento do instrumento. Dentre as alterações propostas pelos projetos citados, podem ser destacados: a supressão da sua composição trifásica (LP, LI e LO), a adição de hipóteses de suspensão de estudos prévios de avaliação de impactos em projetos que apresentem relevante potencial de impacto e a suspensão das hipóteses de participação social no licenciamento.
} 
afeitas à questão ambiental. Para ilustrar os muitos e variados avanços regulatórios realizados na década de 1980 vale citar dois exemplos, um em cada extremo da década, tratando desde o urbano até o rural: (i) a Lei 6.803/1980 que dispõe sobre as diretrizes básicas para o zoneamento industrial nas áreas críticas de poluição; e (ii) a Lei n ${ }^{\circ} 7.802 / 1989$ que dispõe sobre o controle, inspeção e fiscalização de agrotóxicos, seus componentes e afins.

Em relação ao planejamento e gestão ambiental dos territórios lembramos que as bacias hidrográficas já vinham sendo trabalhadas como unidades espaciais para a gestão das águas e seus múltiplos usos. Testemunham isso algumas iniciativas realizadas ainda na década de 1970 pelo Comitê de Estudos Integrados de Bacias Hidrográficas (CEIBH), vinculado ao Ministério do Interior (MINTER). O Macrozoneamento da Bacia Hidrográfica do Rio Paraíba do Sul, elaborado pelo Comitê Executivo de Estudos Integrados da Bacia do Paraíba do Sul (CEEIVAP) e formalizado através do Decreto Federal nº 87.561/1982, resultou de um esforço envolvendo representantes da União, dos governos estaduais e municípios (fluminenses, paulistas e mineiros), assim como representantes da sociedade civil e do setor produtivo ${ }^{14}$.

Ainda em relação à gestão ambiental dos territórios vale lembrar a experiência (bastante questionada quanto a seus reais propósitos e resultados concretos) do Programa de Desenvolvimento da Região Noroeste do Brasil (Polonoroeste, 1980), que foi seguido de outras como a do Plano Agropecuário e Florestal de Rondônia (Pronafloro, 1986) e do Projeto de Desenvolvimento Agroambiental do Mato Grosso (Prodeagro, 1992), todos envolvidos em operações de crédito realizadas com o Banco Internacional para Reconstrução e Desenvolvimento (BIRD). Esses planos/programas foram negocia-

\footnotetext{
14 Contudo, seus efeitos práticos foram em grande medida frustrados, pois as diretrizes estabelecidas no Macrozoneamento do Ceeivap dependiam de sua incorporação aos planos diretores de cada município, dado que a competência para o disciplinamento do uso-ocupação do solo era, desde então, uma prerrogativa dos governos locais.
} 
dos à época como "requisitos" que tornariam o país elegível a outras operações de crédito, especialmente aquelas destinadas a projetos a serem implantados nos biomas do Cerrado e Amazônia ${ }^{15}$.

A construção de um ambiente político-institucional favorável a uma gestão transversal e integrada envolveu (e ainda envolve) barreiras de difícil transposição dada, dentre outros fatores, uma cultura centralista e avessa à cooperação-coordenação entre os vários setores e esferas de governo. Afinal, no cerne da discussão sobre a agenda ambiental, encontram-se muitas das decisões políticas estruturantes que vão definir o destino a ser dado ao território, aos recursos nele contidos e às atividades nele desenvolvidas. As disputas em matéria das competências dos diferentes agentes e esferas de governo fazem com que a gestão ambiental seja um locus de conflitos, conforme apontam Theodoro et al. (2005). Face ao surgimento de um novo "setor" de governo (o "ambiental", que disputava não só competências como também recursos escassos) não surpreenderam as reações contrárias à "hegemonia das agências recém-chegadas", as quais explicavam, ao menos em parte, iniciativas que visavam o isolamento, esvaziamento, enfraquecimento e sucateamento das agências e políticas ambientais. Não surpreendia, também, o fato dessas tentativas terem origem em instâncias, organizações e setores governamentais que, de alguma forma, competiam para definir o uso presente e futuro dos espaços-recursos. Desde sempre estiveram em discussão, ainda que de forma dissimulada, os embates entre óticas preservacionistas, conservacionistas, desenvolvimentistas etc. Também não surpreende o envolvimento direto dos agentes econômicos, na medida que seus interesses e ações poderiam ser "favorecidos" ou, simplesmente, aliviados de "novas, caras, longas e improdutivas exigências burocráticas". Como se vê, essa narrativa, muito presente nos dias de hoje, de nova não tem nada.

\footnotetext{
${ }^{15}$ Tais planos/programas tinham como objetivo, já na década de 1980, acompanhar e ordenar o avanço de atividades de extração de madeira/minérios e de produção de carne/grãos sobre os biomas do Cerrado e Amazônia. Tanto o Pronafloro como o Prodeagro envolveram a elaboração de Zoneamentos Sócio-Econômico-Ecológicos (ZSEE) que, no caso de Rondônia, teve duas versões aprovadas, a primeira em 1988 e a segunda em 2009. Como podemos verificar nos dias de hoje, os resultados dessas iniciativas foram insuficientes, para dizer o mínimo.
} 
Os problemas vividos por algumas das principais agências ambientais estaduais encontram nesse particular, parte importante das razões de ser. Algumas delas viveram momentos muito difíceis a partir da metade da década de 1980 e nunca mais retornaram à condição de centros de excelência que mantinham até então. Ao fazer um balanço da tentativa de resgate da agência ambiental do Rio de Janeiro, Margulis e Gusmão (1997, p. 22 ) indicaram um processo de desprestígio que levou ao sufocamento institucional evidente:

A Feema experimenta hoje uma deterioração institucional dramática e sem precedentes desde que foi criada há 20 anos. Se a administração estadual anterior não atribuiu ao setor qualquer prioridade, a presente tampouco tem sido capaz de reverter essa tendência declinante.

Dentre as razões explicativas - seja da condição de decadência ou das dificuldades de resgate -, os autores assinalaram a falta de suporte político, a debilidade institucional, a limitada autonomia e capacidade gerencial e os limitados recursos e instrumentos de gestão. Nada muito diferente do que seguiu caracterizando esta e outras agências, que se viram transformadas em instituições "para inglês ver" e/ou em instrumentos de manobras políticas rasteiras.

Mas a noção da complexidade desse período e da temática é dada também por outros indicadores como a consagração do tema ambiental pela Constituição Federal de 1988 (Capítulo VI, Art. 225). Esse pode ser tido como o ponto alto da trajetória da regulamentação da questão ambiental. É relevante que destaquemos que essa consagração não resultou só dos avanços realizados no campo específico do aparato político-institucional dedicado à gestão ambiental, mas sobretudo das condições sociais e políticas próprias do período, seja no plano internacional ou, mais especificamente, nacional. A participação direta da sociedade civil no debate da CF88 foi determinante para a elevação das expectativas da sociedade brasileira - dentre elas aquelas relativas ao campo ambiental - materializadas no texto constitucional. A proliferação e profissionalização de Organiza- 
ções Não Governamentais (ONGs) brasileiras, o engajamento de líderes e intelectuais, assim como a fundação do Partido Verde (1986) e a formação da Frente Parlamentar Verde são algumas das evidências desse processo.

Desse mesmo momento faz parte a criação do Instituto Brasileiro do Meio Ambiente e dos Recursos Naturais Renováveis (IBAMA) em 1989, justificada como forma de consolidar um sistema integrado de gestão ambiental, pois reunia as competências, recursos e práticas técnico-administrativas antes alocadas à Secretaria Especial do Meio Ambiente (SEMA/MINTER), ao Instituto Brasileiro de Desenvolvimento Florestal (IBDF) e à Superintendência para o Desenvolvimento da Pesca (SUDEPE), à Superintendência da Borracha (SUDHEVEA). No ano seguinte foi criada a Secretaria do Meio Ambiente da Presidência da República (Semam), à qual passou a estar vinculado o Ibama, funcionando assim como seu braço técnico responsável pela implementação da PNMA. Além das pressões internas, que deram origem a uma vontade política endógena, deve-se destacar ou-

tra vez as pressões internacionais que, movidas pelas desastrosas intervenções realizadas nos biomas do Cerrado e da Amazônia, levaram também à criação do Sistema de Vigilância da Amazônia (SIVAM) e do Sistema de Proteção da Amazônia (SIPAM), ambos em 1990.

\subsection{Consolidação da PNMA, descentralização, neoliberalismo e a governança am- biental}

Dentre as marcas mais notáveis associadas ao início desse novo recorte destacaríamos a Constituição Federal de 1988 e o reforço, por assim dizer, que ela deu à implementação da Lei da Política Nacional de Meio Ambiente de 1981. Sobre essa base de sustentação tornou-se possível assegurar os avanços realizados em direção da constituição 
do sistema nacional de gestão ambiental. A criação, em 1992, do Ministério do Meio Ambiente (MMA) significou um dos desdobramentos da CF88 e a incorporação da questão ambiental pela estrutura superior da gestão pública brasileira ${ }^{16}$.

Outra marca inicial desse recorte envolveu a preparação e realização da Conferência das Nações Unidas sobre Meio Ambiente e Desenvolvimento (mais conhecida como a Rio 92) dando origem a uma gama variada de ganhos. Cabe destacar o fato de que durante cerca de três anos a opinião pública brasileira esteve submetida a um intenso processo informativo que resultou na mobilização e amadurecimento do imaginário da sociedade brasileira sobre o que fosse a questão ambiental17 e suas implicações.

A análise deste recorte deve resgatar a percepção de que até então gestão do território e gestão ambiental representavam práticas estatais que, apesar de tratarem de objetos afins, mantinham-se apartadas. Ressaltamos, outra vez, a inapetência dos setores e esferas governamentais em manterem laços de cooperação e coordenação entre suas respectivas ações e objetivos. A definição e gestão de espaços protegidos e de zoneamentos ecológico-econômicos, bem como de Planos Diretores Urbanos, Planos de Desenvolvimento Local Integrados, Zoneamentos Industriais (sobretudo das Regiões Metropolitanas) e Planos de Bacias Hidrográficas são práticas que deveriam envolver a cooperação-coordenação entre as diferentes esferas e setores governamentais competentes, suas agências e equipes técnicas, em processos decisórios e de diálogo que resultariam em benefício do interesse comum da sociedade e, nesse contexto, da eficácia de suas respectivas ações. Entretanto, cooperação-coordenação em torno da formulação de

\footnotetext{
${ }^{16}$ Desde a Conferência de Estocolmo, os avanços do ponto de vista da estruturação da alta administração federal em matéria ambiental eram considerados insuficientes. Passaram-se 12 anos entre a criação da Sema (1973) e do Ministério de Desenvolvimento Urbano e Meio Ambiente (1985), o que refletia uma institucionalidade bastante parcial do tema. Apesar da criação do Ibama (1989) - reunindo as competências antes dispersas por várias instituições -, só às vésperas da Conferência da Rio 92 foi criada a Secretaria de Meio Ambiente da Presidência da República (Semam, 1990), vinculada diretamente à Presidência da República. Finalmente, em 1992 foi então criado um Ministério com mandato específico para coordenar a formulação e implementação da PNMA.

${ }^{17} \mathrm{~A}$ cientista social Samyra Crespo tem estudado desde então a evolução do que pensa o cidadão brasileiro médio sobre a temática meio ambiente, por meio da pesquisa "O que o Brasileira Pensa do Meio Ambiente e do Consumo Sustentável". Após quatro rodadas da mesma pesquisa (1992, 1997, 2002 e 2012), ficaram evidentes os ganhos em termos do processo de conscientização (mas não necessariamente de comprometimento) da sociedade brasileira a respeito.
} 
políticas públicas nunca representou, desde os tempos coloniais, ponto forte da administração pública brasileira.

Como mais uma iniciativa alinhada à criação do SIVAM e SIPAM, assim como do próprio Ibama, podemos acrescentar a criação do Programa de Zoneamento EcológicoEconômico da Amazônia Legal (PZEEAL) em 1991 para ser executado no âmbito da Secretaria de Assuntos Estratégicos (SAE, 1990) vinculada à Presidência da República (1990). A consolidação das políticas ambientais, até então protagonizada por especialistas de áreas específicas, tais como engenharia, biologia e saúde pública, ganhou uma perspectiva interdisciplinar a partir da contribuição de outras áreas do conhecimento (geografia, economia, urbanismo, sociologia, antropologia etc.). A contribuição da geografia brasileira fez diferença, especialmente no tocante a regiões de fronteira como a Amazônia, podendo ser destacadas contribuições dadas por iniciativas e trabalhos como os realizados por Valverde ${ }^{18}$, Ab'Sáber $^{19}$, Becker $^{20}$, Egler ${ }^{21}$, Coelho ${ }^{22}$ e Porto-Gonçalves ${ }^{23}$ para citar alguns poucos, que colaboraram no sentido do reconhecimento da gestão ambiental como parte da gestão do território, especialmente no caso dos biomas Amazônia, Cerrado e Pantanal.

A longa trajetória das experiências com os Zoneamentos Ecológicos-Econômicos (ZEEs) está associada a um crescente interesse pelos diálogos integrados entre setores, agentes e escalas, conforme assinalado pelo MMA na apresentação da versão final do Macrozoneamento Ecológico-Econômico da Amazônia Legal (2020)

O MacroZEE dialoga e mantém uma relação de mão dupla com as principais iniciativas que já estão transformando a Amazônia e que contam com forte legitimação política e social, no geral referenciadas no Plano Amazônia Sustentável (PAS), como, por exemplo, o Plano de Ação para Prevenção e Controle do Desmatamento na Amazônia (PPCDAm), as Políticas de

\footnotetext{
${ }^{18}$ Cf. Valverde (1979) e Valverde e Freitas (1980).

${ }^{19}$ Cf. Ab’Sáber (1980 e 1997).

${ }^{20}$ Cf. Becker (1982).

${ }^{21}$ Cf. Becker e Egler (1997).

${ }^{22}$ Cf. Coelho (1997).

${ }^{23}$ Cf. Porto-Gonçalves (2001).
} 
Desenvolvimento Regional (PNDR) e de Defesa (PND), o Plano Nacional sobre Mudança do Clima (PNMC), o Programa Territórios da Cidadania, os Planos de Desenvolvimento Regionais, a exemplo dos Planos Marajó, BR163 e Xingu, o Programa de Regularização Fundiária da Amazônia Legal (Terra Legal), a Lei de Gestão de Florestas Públicas (lei federal $\mathrm{n}^{\circ}$ 11.284/2006), o Programa de Manejo Florestal Comunitário e Familiar (decreto federal $\left.n^{\circ} 6.874 / 2009\right)$ e o Plano Regional de Desenvolvimento da Amazônia (PRDA). ${ }^{24}$

Existem, contudo, várias barreiras a serem enfrentadas, as quais permanecem como desafios em 2020. Dentre aquelas assinaladas pelo MMA como barreiras à elaboração e implementação do MacroZEE, destaca-se a "baixa implementação das ações previstas" explicada por fatores, tais como:

[...] a dificuldade de apropriação dos resultados do ZEE pelos gestores públicos, particularmente nos municípios do interior da Amazônia Legal, muitas vezes alheios à elaboração do zoneamento e desacostumados a uma cultura integrada de planejamento.

[...] a baixa participação de diferentes setores da sociedade na elaboração e implementação do ZEE, em especial o setor privado, associada, principalmente, (i) à baixa compreensão da finalidade do instrumento, (ii) à percepção equivocada de que o instrumento, muitas vezes, prioriza a preservação ambiental, em detrimento das questões produtivas e sociais, (iii) ao descrédito quanto à fiscalização e à penalização no caso de não observância das diretrizes e estratégias do ZEE, e (iv) ao fato de que, em diversas oportunidades, o ZEE é visto apenas como um requisito burocrático para a redução da Reserva Legal nos imóveis rurais situados na Amazônia Legal (MMA, 2020, p. 90-91, grifo nosso).

O recorte temporal 1990-2010 também ficou marcado pela descentralização da gestão ambiental, para o que pesou, dentre outros fatores, a elevação dos municípios à condição de entes federativos e, portanto, corresponsável pelo dever de defender e preservar o meio ambiente para as presentes e futuras gerações como previsto no Art. 225 da

\footnotetext{
${ }^{24}$ MACROZONEAMENTO ECOLÓGICO-ECONÔMICO (MacroZEE) DA AMAZÔNIA LEGAL (aprovado pelo Decreto $\mathrm{n}^{\circ}$ 7.378/2010), citações extraídas do site do MMA, visitado em 11/05/2020.
} 
Constituição Federal de 1988. Com isso foram redefinidas competências que aproximavam ainda mais a gestão ambiental em relação à gestão do território, notadamente no que se refere à sua parcela urbana. Contudo, como não houve o mesmo cuidado com os recursos (ou, em português mais claro, o real poder decisório), ficaram frustradas em boa medida as vantagens da descentralização face à assimetria entre competências e possibilidades reais dos municípios. A intenção do legislador ao criar a Lei da Política Nacional do Meio Ambiente e sua inspiração descentralizadora, participativa e colegiada (refletida, por exemplo, na instituição do SISNAMA e do CONAMA) manteve-se no plano de uma descentralização de papel, na medida em que permaneceu o regime de tutela exercida pela União, (re)alimentando relações históricas de clientelismo que tipificam a gestão pública brasileira.

A ampliação dos fóruns e instrumentos de democracia participativa é também assinalada por Gusmão e Pavão (2019) como avanço dedicado à descentralização e governança ambiental do território. Essa tendência, formalizada inicialmente pela PNMA (Lei $\left.\mathrm{n}^{\circ} 6.938 / 1981\right)$, ampliou as possibilidades de mediação dos conflitos com efeitos sobre a qualidade ambiental das cidades, das áreas florestadas, dos meios rurais e agrários, assim como dos corpos hídricos (doces, salgados e salobros) e outros recursos ambientais. Contudo, como destacado pelos mesmos autores

\begin{abstract}
esses novos arranjos institucionais estão submetidos às limitações derivadas, por exemplo, de aspectos retrógrados e centralizadores próprios da estrutura federativa brasileira e, frequentemente, da desigual distribuição social do acesso às redes de poder e do protagonismo exercido por certos agentes econômicos. As limitações à participação nas mesas de negociação, assim como as pressões exercidas por certos agentes no interior desses fóruns (e dos espaços geográficos sob sua tutela), representam impedimentos ao propósito de promover processos decisórios justos (GUSMÃO; PAVÃO, 2019, p. 50).
\end{abstract}

Outro destaque referente ao recorte 1990-2010 envolve uma forte agenda de desregulamentação na área ambiental, a qual tomava por base o ideário neoliberal de que 
os agentes econômicos poderiam e deveriam exercer uma parcela maior de responsabilidades (por vezes em caráter voluntário), porque isso significaria "bons resultados com mais racionalidade para os agentes econômicos e menos custos para o Estado". Esse pacote de reformas do sistema brasileiro de gestão ambiental previa a internalização de processos e instrumentos experimentados em outros contextos, tais como: certificação ambiental (processos e produtos), autorregulação e licenciamento auto declaratório, mercado de créditos de carbono e licenças intercambiáveis.

A década de 2000 ficou marcada pelo boom das commodities a nível mundial (sobretudo, no caso brasileiro, minérios, grãos e proteína animal) que demandou grandes projetos de infraestrutura (sobretudo geração de energia e transportes) que resultaram em novas pressões sobre o sistema brasileiro de gestão ambiental, especialmente sobre os processos de licenciamento ambiental. O licenciamento ambiental da usina de Belo Monte, das hidroelétricas da bacia do Rio Madeira e do Complexo Petroquímico do Rio de Janeiro (COMPERJ) são exemplos desse tipo de problema.

Destaque-se que os conflitos entre os agentes (públicos, sociais e econômicos) e suas divergências em termos de interesses, visões de mundo (ou projetos de sociedade) sempre fizeram e farão parte da dinâmica de qualquer democracia. Os embates entre diferentes políticas preservacionistas, conservacionistas, desenvolvimentistas etc. estiveram presentes nesse período como evidencia a agenda dos megaprojetos constantes dos Planos Brasil em Ação (1996, governo Fernando Henrique Cardoso), Avança Brasil (2000, governo Fernando Henrique Cardoso) e Plano de Aceleração do Crescimento - PAC (2007, governos Luiz Inácio Lula da Silva e Dilma Rousseff). Esses planos, que envolveram grandes investimentos concentrados, sobretudo em rodovias, estradas, portos e geração de energia, obedeciam a um viés desenvolvimentista, parte de uma estratégia que visava colocar a economia brasileira como fornecedora mundial de produtos primários e semielaborados, tais como minério de ferro, aço bruto, proteínas animais, grãos e petróleo ${ }^{25}$.

\footnotetext{
${ }^{25}$ Em relatório visando subsidiar a formulação da Política Nacional de Ordenamento Territorial (PNOT) coordenado por Becker (2006), os autores chamam a atenção para o papel desempenhado pelas grandes corporações e pelos grandes projetos no processo de reestruturação do espaço, cabendo-Ihes responsabilidades no que se refere ao
} 
A combinação dos ideais liberais e dos projetos desenvolvimentistas deu origem a momentos de tensão e conflitos que, contudo, não deram lugar a uma proposta de "virada de mesa" sistemática e generalizada.

A consolidação de experiências deu margem, nos últimos anos da década de 1990 e ao longo da primeira década de 2000, a um conjunto de diplomas legais que ajudavam a complementar o marco legal elaborado ao longo das décadas anteriores. Salta aos olhos o fato desses novos instrumentos representarem movimentos numa mesma direção e terem sido aprovados concentradamente num espaço de tempo relativamente curto. Eles evidenciam, portanto, um processo de amadurecimento e estabilização do marco legal-institucional da gestão ambiental no país. São os seguintes os diplomas legais que consideramos mais importantes:

- a Lei n 9.433/1997, da Política Nacional de Recursos Hídricos (contendo os resultados de debates e experimentos desenvolvidos desde os anos 1970), que institui o Sistema Nacional de Gerenciamento de Recursos Hídricos e o Conselho Nacional de Recursos Hídricos $(\mathrm{CNRH})^{26}$;

- a Resolução CONAMA ñ 237/1997, que complementa o ordenamento do licenciamento ambiental, estabelecendo as competências das diferentes esferas de governo;

- a Lei n 9.605/1998, que consolida e disciplina de forma integrada os Crimes Ambientais, que na sua maioria eram regulados por diplomas que, por terem sido gerados em diferentes contextos e épocas, tratando de diferentes temáticas, muitas vezes conflitavam entre si;

\footnotetext{
agravamento de certas desigualdades regionais. Os autores assinalam também que a implantação-ampliação dos portos brasileiros teve como objetivo principal dar suporte às exportações de commodities. Em vários casos eles se tornaram parte integrante de longas cadeias produtivas de agentes que, muitas vezes, operam ao longo das mesmas, seja na produção das commodities como na operação de redes terrestres de transportes e terminais portuários que escoam tal produção. Nessa linha, referindo-se às redes ferroviárias e às exportações brasileiras, os autores concluem que elas seguem, grosso modo, o padrão histórico de conexão das áreas produtoras aos portos, formando assim "territórios logísticos de escoamento" alinhados à lógica dos negócios dessas empresas e não necessariamente com a promoção do desenvolvimento local ou regional.

${ }^{26}$ Destaque-se que a composição inicial do CNRH veio a ser severamente descaracterizada por força do Decreto $\mathrm{n}^{\circ}$ 10.000 de 03/09/2019.
} 
- a Lei nº 9.795/1999, versando sobre a Política Nacional de Educação Ambiental, definindo estratégias e instrumentos, dando assim um ordenamento a atividades muito diversas;

- a Lei n 9.985/2000, que instituiu o Sistema Nacional de Unidades de Conservação (SNUC), sistematizando e consolidando um conjunto de normas uniformizando a gestão de diferentes tipos de unidades de conservação, muitas delas associadas a controvérsias e conflitos;

- a Lei n 9.984/2000, que instituiu a Agência Nacional de Águas e Saneamento Básico (ANA), agência responsável pela realização de atividades de regulação, monitoramento, planejamento e apoio à gestão das águas;

- a Lei $n^{\circ} 10.257 / 2001$, que aprovou o Estatuto da Cidade, que estabelece normas de ordem pública e interesse social que regulam o uso da propriedade urbana em prol do bem coletivo, da segurança e do bem-estar dos cidadãos, bem como do equilíbrio ambiental;

- a Lei $n^{\circ} 11.107 / 2005$, que regulamentou a figura dos Consórcios Públicos, definindo e ordenando as possibilidades de cooperação-coordenação entre esferas e unidades governamentais, especialmente face a problemas que transcendem seus limites político-administrativos;

- a Lei $n^{\circ} 11.428 / 2006$, que regulamentou a proteção da vegetação nativa do bioma Mata Atlântica;

- o Decreto n ${ }^{\circ}$ 6.040/2007, que estabelece a Política Nacional de Desenvolvimento Sustentável dos Povos e Comunidades Tradicionais;

- a Lei no 11.516/2007, que cria o Instituto Chico Mendes de Conservação de Biodiversidade (ICMBio) com o propósito de gerir as Unidades de Conservação federais e apoiar a implementação do Sistema Nacional de Unidades de Conservação (SNUC); 
- a Lei $n^{\circ} 11.445 / 2007$, que estabelece as diretrizes que orientam a Política Federal de Saneamento Básico e cria o Comitê Interministerial de Saneamento Básico, regulando o tema na perspectiva de uma política Ambiental27;

- a Lei no 12.187/2009, que cria a Política Nacional do Clima (PNMC), o primeiro marco legal para atuação em relação ao desafio do século XXI a nível nacional, estabelecendo seus princípios, objetivos, diretrizes e instrumentos;

- a Lei $n^{\circ} 12.305 / 2010$, que tratou do Plano Nacional de Resíduos Sólidos visando à universalização dos serviços de coleta, tratamento e disposição final, avançando na definição das responsabilidades pós-consumo;

- A Lei Complementar n 140/2011, que fixa normas visando melhor delimitar a distribuição das competências entre os estados, municípios e União para a proteção do meio ambiente, bem como trata da cooperação entre os entes.

Esse conjunto de diplomas não significa que a construção de um sistema de gestão estivesse concluída. Contudo, fica evidente que ao cabo de quatro décadas a partir de 1970, guardando-se cautela quanto à avaliação e aperfeiçoamento desse conjunto de instrumentos, o país aparentava dispor de um ordenamento sistemático orientador do tratamento da temática, com sua complexidade e particularidades.

Importa levar em conta também o amadurecimento de políticas ambientais regionais como no caso da Amazônia. Ainda que contando com apoios internacionais, é de se reconhecer que existiu nesse período um conjunto articulado de planos e programas que refletiam uma certa continuidade/consistência, assim como uma capacidade endógena de negociar. Referimo-nos, dentre outros: (i) ao Programa Piloto Internacional de Proteção das Florestas Tropicais no Brasil (PPG7, 1993-2009); (ii) ao Plano Amazônia Sustentável (PAS, 2008) estabelecendo diretrizes para orientar o desenvolvimento com valorização da diversidade sociocultural e ecológica, assim como a redução das desigualdades

\footnotetext{
${ }_{27}$ Importante mencionar que em 24/06/2020 foi aprovado o Projeto de Lei $n^{\circ} 4.162$, que altera a Política Nacional de Saneamento Básico.
} 
regionais; e (iii) ao Fundo Amazônia (2008), gerido pelo BNDES, que visava captar doações para investimentos não reembolsáveis em ações de prevenção, monitoramento e combate ao desmatamento, e promoção da conservação e uso sustentável da Amazônia Legal.

A experiência do Programa Piloto Internacional de Proteção das Florestas Tropicais no Brasil (PPG7) representou uma mudança radical em relação às estratégias de desenvolvimento da região amazônica, especialmente pela forma como foi encarada a governança do Programa pelo Governo Brasileiro e pelos parceiros internacionais. Conforme Gerd Kohlhepp:

a estrutura de coordenação do Programa Piloto, iniciado em 1993, mostrou a função central desempenhada pelo Ministério do Meio Ambiente (MMA) do lado brasileiro que, em cooperação com outros ministérios (Justiça, Ciência e Tecnologia), organizou o projeto. Uma comissão científica internacional independente (International Advisory Group - IAG1), cujos 11 membros foram propostos pelo Banco Mundial, pelos países G7 e pelo Governo Brasileiro com base em sua expertise sobre a Amazônia, desempenhou a função de consultoria durante todo o tempo do Programa. Depois de inúmeras reuniões de trabalho, visitas a regiões de relevância e análise de projetos, foram apresentadas sugestões específicas para o andamento do Programa e para a execução de Projetos (KOHLHEPP, 2018, p. 314).

Retornando aos avanços em matéria legal e, ao mesmo tempo, à ideia de que momentos de tensão e conflitos sempre estiveram presentes, o início da década de 2000 foi também marcado pela propositura da PEC n 215/2000, que traduz alguns dos principais interesses da corrente desenvolvimentista, propondo atribuir/transferir competências do Poder Executivo para o Legislativo, repassando ao Congresso Nacional a competência para aprovar a demarcação de Terras Indígenas (TI) e quilombolas e Unidades de Conservação (UCs). Um dos pontos mais controvertidos do projeto refere-se à possibilidade de indenização dos proprietários das terras e o marco temporal de 05 de outubro de $1988^{28}$

\footnotetext{
${ }^{28}$ Data de publicação da Constituição Federal de 1988.
} 
para a definição do que são terras permanentemente ocupadas por quilombolas e indígenas. $O$ projeto, ainda em tramitação, abriu alas para as diversas propostas apresentadas ao longo desta década.

Como já mencionado, o licenciamento ambiental de vários grandes projetos ficou marcado por conflitos envolvendo setores e unidades do próprio aparato governamental federal. O caso das hidroelétricas de Belo Monte e da bacia do Rio Madeira, na esfera federal, assim como do COMPERJ, todos os três já mencionados, representam casos emblemáticos.

Foi marcante o embate público estabelecido entre o Ministério de Minas de Energia (Ministra Dilma Rousseff à frente) e o Ministério do Meio Ambiente (Ministra Marina Silva à frente) a propósito do licenciamento das usinas hidroelétricas do Rio Madeira. Esse embate durou semanas e resultou em dois fatos destacáveis: (i) a liberação da Licença Prévia pelo Ibama em favor do início da obra; e (ii) a demissão da Ministra Marina Silva que, pelo desgaste sofrido, desligou-se não só do governo Lula, mas também do Partido dos Trabalhadores (PT). No caso do COMPERJ, os fatos ocorridos envolveram uma dura negociação entre a Petrobrás (com o apoio do mesmo Ministério das Minas e Energia) e a Secretaria do Ambiente do Rio de Janeiro (Secretário Carlos Minc à frente) da qual resultou a injeção de recursos (inclusive humanos) no INEA (Instituto Estadual do Ambiente, agência ambiental estadual) visando a agilização do processo de licenciamento do Complexo.

Mereceria um exame mais cuidadoso a criação do Instituto Chico Mendes de Conservação da Biodiversidade (ICMBio) em 2007, para o qual foi deslocada a gestão das unidades de conservação federais, até então conduzida pelo Ibama, na gestão da ministra Marina Silva. Sobre essa alteração, duas reflexões poderiam ser arguidas. A criação de uma nova instituição federal para cuidar prioritariamente desta agenda consistiria em um ganho em dois sentidos: (i) maior clareza da missão, foco e objetivos; e (ii) melhor gestão em termos de recursos humanos, materiais e financeiros. Em contraponto, a separação 
entre Ibama e ICMBio poderia sugerir uma fragmentação e enfraquecimento institucional, uma "vitória" na queda de braço envolvendo, de um lado, os ideais preservacionistas e, de outro, os interesses desenvolvimentistas. Sendo assim, admitir-se-ia a hipótese de que a fragmentação institucional ensejaria uma ação menos coordenada entre a preservação da agenda verde (defendida pelo ICMBio) e a agenda marrom (ou o licenciamento ambiental realizado pelo Ibama). Fato é que a instituição do Ibama (1989), consolidando as agendas verde e marrom, estaria sendo revista através da criação do ICMBio (2007) sem que a decisão tivesse passado por uma análise pública e participativa ${ }^{29}$.

Apesar de problemas quanto às diferenças em termos de ênfases e objetivos perseguidos - conservacionistas, preservacionistas, desenvolvimentistas etc. - e dos conflitos vividos - que em português corrente podem ser considerados como parte do jogo -, é preciso reconhecer que ao longo desse recorte 1990-2010 prevaleceu uma certa continuidade das gestões e instituições, assim como da legislação e práticas técnico-administrativas consolidadas até então. Desde a criação do MMA, passaram pelo cargo de ministro personagens tais como José Goldemberg, Gustavo Krause, José Sarney Filho, José Carlos de Carvalho, Marina Silva, Carlos Minc e Izabella Teixeira. Ainda que a sucessão de tais personagens sugira diferenças de estilos e até mesmo de ideais, é fato que não podem ser percebidos movimentos abruptos de mudanças políticas, institucionais ou jurídicas. Ainda que se possa lamentar a forma como se deu seu desligamento da pasta-governo-partido, a presença de (Marina Silva) uma ativista ambiental com raízes no movimento dos seringueiros, contemporânea de Chico Mendes, pode ser tida como um cartão de visitas de bom tamanho. Por outro lado, o fato de o Geógrafo Aziz Ab'Saber ter sido sondado para o cargo de ministro do MMA no primeiro governo Lula é outra indicação bastante positiva.

Enfim, ao longo do recorte 1990-2010 não foi registrado qualquer movimento sistemático, coordenado e intencional de revisão do modo (descentralizado, colegiado e

\footnotetext{
${ }^{29}$ Esse tema volta a ganhar destaque face à recente iniciativa do MMA de constituir um grupo de trabalho interno, sem previsão de debate público, no âmbito do qual está colocado um projeto de reunificação do Ibama e ICMBio.
} 
democrático) que caracterizou a formulação das políticas públicas ambientais. Aqui e ali podem certamente ter ocorrido divergências, escaramuças, vitoriosos e derrotados - coisas do jogo democrático, poderia alguém dizer -, mas não uma virada de mesa. Percebese, em resumo, um processo de construção que se iniciou em 1973 e dentro do qual as regras do jogo foram razoavelmente preservadas e os arranjos políticos-institucionais-jurídicos em vários casos aperfeiçoados.

\subsection{Retorno do estilo autoritário e a convergência de interesses para a descons- trução de 40 anos de trabalho}

A década de 2010 ficou marcada por movimentos contraditórios no tocante à agenda ambiental. De um lado, presenciamos avanços importantes na agenda da Mudança do Clima e dos ambientes urbanos, como a promulgação da Política Nacional de Adaptação à Mudança do Clima (2016) e a promulgação da Lei no $13.089 / 15$ que aprovou o Estatuto da Metrópole, ampliando as possibilidades e esclarecendo as responsabilidades no tocante à gestão ambiental urbana na escala metropolitana. Também merece destaque, o fato de que no ano de 2012, o Instituto Nacional de Pesquisas Espaciais (Inpe) registrou o menor índice histórico de desmatamento da Amazônia, refletindo em alguma medida, uma política até então bem-sucedida, construída ainda na gestão da ministra Marina Silva (2003-2008) e que foi endossada pelo seu sucessor Carlos Minc (2008-2010), culminando nos índices históricos observados no mandato de Izabella Teixeira (20102016).

Contudo, neste mesmo momento observou-se um alinhamento de forças cujas ideologias convergiam em direção ao favorecimento de um padrão liberal da economia acompanhado, notadamente, pela busca da flexibilização da regulamentação ambiental vigente. Como marco inicial do sucesso deste alinhamento, foi promulgada a Lei $n^{\circ}$ 12.651/2012 que aprovou o novo Código Florestal Brasileiro, podendo ser considerado um passo largo e preciso em direção à consolidação da flexibilização do aparato normativo 
que embasa o funcionamento do sistema brasileiro de gestão ambiental. Sobretudo, no contexto econômico que o Brasil se insere como grande exportador de grãos e proteína animal no cenário mundial - condição essa favorecida pelas "inovações" contidas no novo Código. Essas "inovações", envoltas ainda em polêmicas, dizem respeito diretamente à possibilidade de controle das atividades agropecuárias na medida em que redefine as APPs, Reservas Legais, além de anistiar os desmatamentos ilegais em terras privadas até julho de 2008.

Nessa mesma linha, entretanto, o tom da década está mais alinhado com iniciativas de projetos de leis que passaram a tramitar no Congresso Nacional com o intuito de flexibilizar ou mesmo eliminar o licenciamento ambiental. A primeira proposta nessa direção foi o Projeto de Lei n 3.729/2004, conhecido como "Lei Geral do Licenciamento". Contudo, o debate sobre a flexibilização desse instrumento ganhou força com o Projeto de Emenda Constitucional nº5/2012. A PEC nº5/2012 é uma das propostas mais veementes no sentido da descaracterização do procedimento de licenciamento ambiental, uma vez que propõe a simplificação/flexibilização do licenciamento ambiental de projetos com significativo impacto ambiental, acrescentando o Parágrafo $7^{\circ}$ ao art. 225 da CF no qual constaria que "a apresentação do estudo prévio de impacto ambiental importa autorização para a execução da obra, que não poderá ser suspensa ou cancelada pelas mesmas razões a não ser em face de fato superveniente". Apesar dessa PEC ter sido arquivada, por si só, ela evidenciou os objetivos de vários e poderosos setores de atividade que não perderão outras oportunidades de batalhar em favor de seus interesses e bandeiras.

Três anos depois, teve início a tramitação no Senado do Projeto de Lei nº 654/2015. Esse PL, ainda em tramitação ${ }^{30}$, dispõe "sobre o procedimento de licenciamento ambien-

${ }^{30}$ Consulta realizada em 07/07/2020. 
tal especial (grifo nosso) para empreendimentos de infraestrutura considerados estratégicos e de interesse nacional" ${ }^{1}$. A principal motivação para a proposição de um "licenciamento ambiental especial" centra-se na argumentação de que o procedimento vigente é moroso, sobretudo em razão de sua composição trifásica ${ }^{32}$. Para Fearnside (2016), tais propostas representam uma forma de facilitar a instalação de grandes empreendimentos tais como hidrelétricas e estradas na região Amazônica. Ainda em 2015, no âmbito do Senado Federal, foi proposto o PL n ${ }^{\circ}$ 602/2015, que dispõe sobre a criação do Balcão Único do Licenciamento Ambiental, estabelecendo procedimentos específicos para obras consideradas estratégicas e prioritárias para o Estado. A proposta prevê que a composição do Balcão Único seja feita apenas por órgãos governamentais, sem previsão de mecanismo de consultas à sociedade civil.

Mais recentemente foi também proposto o Projeto de Lei n 168/2018, que trata da “Lei Geral de Licenciamento Ambiental”. Dentre as alterações previstas, propõe excluir o ICMBio, assim como as agências estaduais responsáveis pela gestão das áreas protegidas, dos processos que envolvem o licenciamento de projetos que afetam essas áreas. $\mathrm{O}$ PL limita a definição de Área de Influência do empreendimento ao recorte espacial onde incidem apenas os Impactos Diretos do empreendimento, excluindo assim, de fato, as hipóteses de Impactos Indiretos.

Tais propostas coincidem em propor alterações no que tange à definição dos prazos (no sentido da sua redução) e maior agilidade dos processos, assim como a eliminação do processo trifásico e a simplificação de regras, convergindo para uma licença única. A argumentação usada alega a necessidade de um ambiente regulatório mais estável, a redução da insegurança jurídica dos investidores. Também consta a proposta de supressão da participação da sociedade civil (ou adoção de consultas facultativas), sobretudo quando se tratar de grandes empreendimentos, ditos "estratégicos". As alterações já vigentes e aquelas em tramitação levantam preocupações face à importância do instituto

\footnotetext{
31 BRASIL. Projeto de Lei do Senado PLS nº 654/2015. Disponível em: <https://www25.senado.leg.br/web/atividade/materias/-/materia/123372>.

32 Licença Prévia (LP), Licença de Instalação (LI) e Licença de Operação (LO).
} 
do licenciamento ambiental (e do estudo de impacto ambiental) como instrumento de planejamento e gestão ambiental territorial.

Ainda sobre as propostas de flexibilização da legislação ambiental que ganham corpo na década de 2010, cabe também mencionar o Projeto de Lei $n^{\circ} 6.299 / 2002$, que voltou a ser debatido e aprovado numa Comissão Especial da Câmara de Deputados em 2018. Através desse $\mathrm{PL}$, ainda em tramitação 33 , pretende-se mudar a regulação do uso de agrotóxicos no país que data de 1989 - este PL ficou popularmente conhecido como o "PL do Veneno". Dentre as modificações que ele introduziria no ordenamento da matéria, destacamos que a proibição do uso de substâncias tóxicas (ou "defensivos agrícolas") ocorrerá apenas em casos em que elas sejam identificadas como apresentando "riscos inaceitáveis". Na prática, isto significa que cerca de 14 substâncias conhecidas como cancerígenas e mutagênicas, as quais são proibidas em diversos países europeus, seriam liberadas no país. Além disso, também propõe menor autonomia do Ibama e MMA na liberação das substâncias, ficando a cargo do Ministério da Agricultura, Pecuária e Abastecimento (Mapa) o papel central. Fazendo uso do dito popular, essa inversão de ordem corresponde a "colocar a raposa para cuidar do galinheiro".

Além dos propósitos e das implicações das alterações no marco legal ambiental (sejam as que ainda tramitam ou aquelas já aprovadas e promulgadas) chama atenção o caráter centralizado (ou por vezes monocrático, no caso das alterações infralegais feitas através de portarias, normas internas etc.) que contraria de frente o modo participativo e colegiado do processo decisório tal como praticado no país desde os anos 1980.

Finalizando, não poderíamos deixar de associar os eventos relacionados a esse recorte temporal com o processo de impedimento da Presidente Dilma (2016), o qual deu lugar à posse do então Vice-Presidente (Michel Temer) e à introdução de mudanças estratégicas no ordenamento jurídico nacional em favor da implantação da agenda neoli-

33 Conforme consulta realizada em 01/12/2020 ao site da Câmara Legislativa, disponível em: <https://www.camara.leg.br/proposicoesWeb/fichadetramitacao?idProposicao=46249>. 
beral, inclusive e especialmente no que se refere ao trato da questão ambiental. A construção das bases para a aprovação do novo Código Florestal (2012) guarda semelhança às que viabilizaram o "golpe" de 2016 e o sucesso de um candidato de extrema direita nas eleições presidenciais de 2018. Os demais fatos/eventos relacionados "vêm a reboque", como se diz no linguajar popular.

\section{Ricardo Salles e a desconstrução do marco político-institucional: Um projeto de governo?}

A ascensão de Jair Bolsonaro à Presidência da República remobilizou, portanto, as preocupações de ambientalistas, cidadania e especialistas quanto à flexibilização da regulamentação e ao desmonte do marco político-institucional ambiental brasileiro. A origem de tais preocupações fundamentava-se, inicialmente, nas declarações realizadas pelo, então, candidato à presidência sobre a condução das políticas ambientais durante seu governo. As declarações a propósito da extinção do Ministério do Meio Ambiente (MMA) ou sua fusão com o Ministério da Agricultura, Pecuária e Abastecimento (Mapa) ganharam destaque em todos os meios e mídias ${ }^{34}$.

Confirmada a eleição de Jair Bolsonaro, restava verificar se as polêmicas declarações realizadas por ele viriam a se concretizar. Após idas e vindas, assim como entrevistas que lembravam um processo seletivo para contratação de um executivo competente para uma missão já definida, Ricardo Salles foi designado ministro do MMA. Embora a eliminação (ou fusão) do ministério não tenha se confirmado, logo nos primeiros meses do novo governo os temores sobre como viria a ser conduzida a política ambiental se confirmavam. As informações disponibilizadas apontavam no sentido de alterações na

\footnotetext{
34 Disponível em: <https://g1.globo.com/natureza/pantanal/noticia/2020/10/15/com-25-mil-focos-de-incendio-em-14dias-pantanal-ja-tem-segundo-pior-outubro-da-historia.ghtml>. Acesso em 13/08/2020.
} 
composição e funcionamento de fóruns participativos com relevantes atribuições na formulação das políticas ambientais. Foi o caso do CONAMA, que veio recentemente a ser reformulado, tendo sua plenária sido reduzida pela exclusão radical de representações extremamente relevantes (como a dos estados e da sociedade civil).

Uma das primeiras alterações estruturantes realizadas pelo governo de Jair Bolsonaro disse respeito à ressubordinação da ANA e CNRH ao Ministério do Desenvolvimento Regional, conforme já citado. Além disso, o Serviço Florestal Brasileiro, responsável pelo Cadastro Rural Ambiental (CAR), importante instrumento para a implementação do Código Florestal e o controle do desmatamento, foi transferido para o Mapa. Não surpreende o fato de o CAR ter passado da condição de um avanço para a de mais uma formalidade burocrática, ou pior, um meio de facilitar a legalização de terras desmatadas e ocupadas ilegalmente. Cabe destaque ainda às alterações promovidas no âmbito do ICMBio (Decreto $n^{\circ}$ 10.234/2020) que, dentre outras disposições, extinguiu as 11 (onze) coordenações regionais, criando em seu lugar cinco (5) gerências correspondentes às macrorregiões do país.

Fruto da falta de prestígio do sistema ambiental e de uma política econômica fiscalista, foram implementados cortes orçamentários nas diferentes agências e agendas ambientais, como, no emblemático caso da Agenda de Mudança do Clima, das políticas a ela dedicadas. Por outro lado, ganharam forma projetos de lei com impactos socioambientais importantes como o que altera as regras sobre a liberação de atividades econômicas em Terras Indígenas, inclusive a mineração ${ }^{35}$.

Consequência de mudanças políticas, cortes orçamentários ou simples esvaziamento das instituições e atividades de controle, passou-se a assistir, ainda no primeiro ano da gestão de Ricardo Salles, a um expressivo aumento das taxas de desmatamento na região da Amazônia Legal, as quais, a bem da verdade, já vinham crescendo desde o governo Michel Temer (agosto/2016 a dezembro/2018). Não parece simples coincidência

35 Consultar documento elaborado pela ASCEMA, publicado em 04 setembro de 2020, disponível em: <https://www.poder360.com.br/brasil/servidores-enviarao-dossie-contra-politica-ambiental-de-bolsonaro-a-onu/>. 
o fato do ano de 2019 ter apresentado a maior taxa de desmatamento desde 2009, representando o acréscimo de uma área de $10.100 \mathrm{~km}^{2}$ onde a cobertura vegetal foi eliminada, conforme assinalado no Gráfico 1 a seguir.

\section{Gráfico 1 - Variação nas taxas de desmatamento $\left(\mathrm{em} \mathrm{km}^{2}\right)$ na Amazônia Legal (2009-2019).}

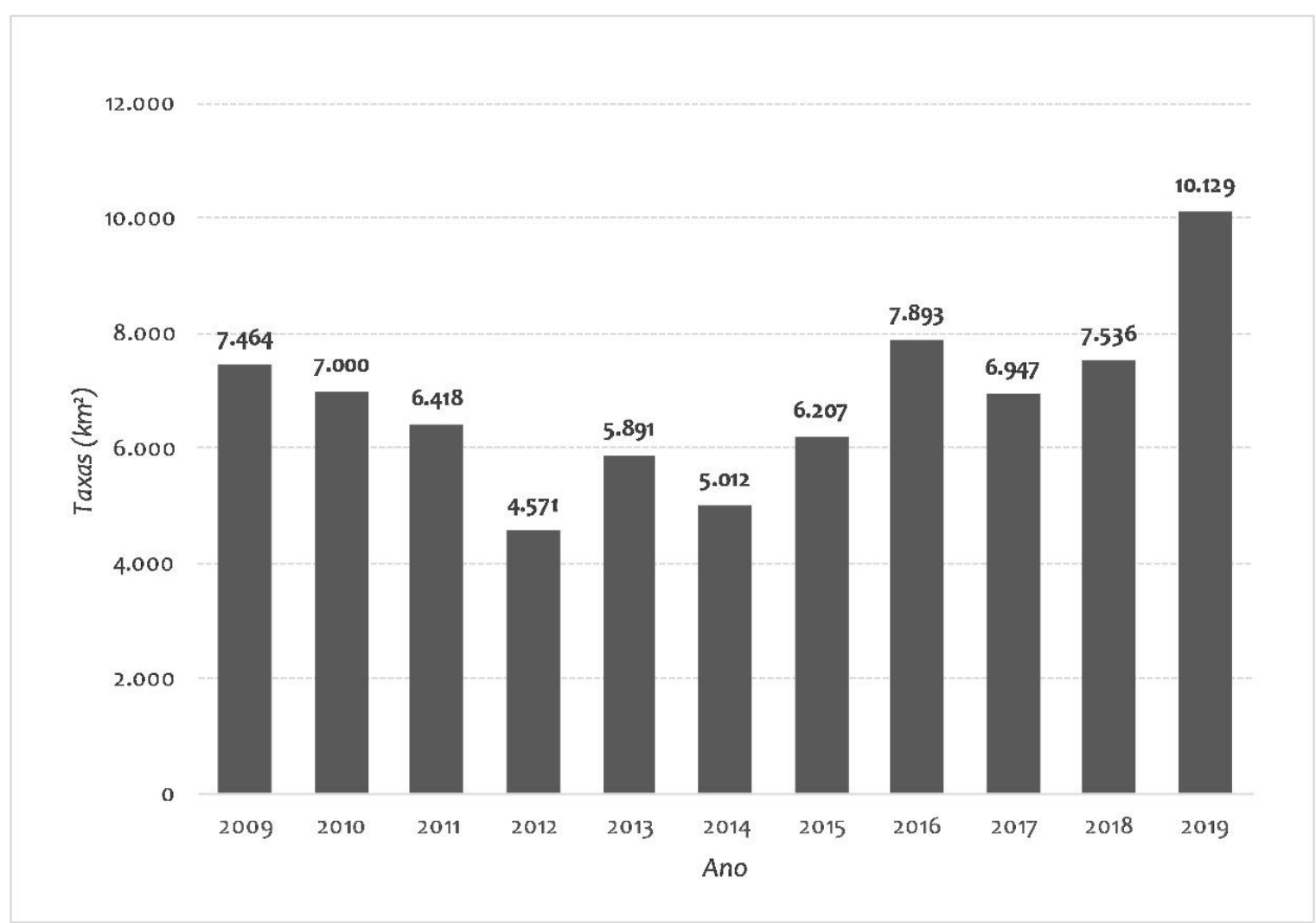

Fonte: PRODES/INPE, 2019. Elaboração própria, 2020.

É fato que os índices de desmatamento na região da Amazônia Legal sempre passaram por oscilações. Contudo, chamou a atenção o aumento de $34,4 \%$ das taxas de desmatamento entre os anos de 2018 e 2019, assim como as respostas institucionais que se mostraram inversamente proporcionais, como se verifica no Gráfico 2. Consta que o orçamento do Ibama experimentou em 2020 uma diminuição da ordem de 23\% nas verbas 
destinadas à preservação e ao controle de incêndios florestais, cujo alvo principal acaba sendo a região Amazônica ${ }^{36}$.

A redução das condições financeiras, de pessoal, materiais e logísticas nesse período pode explicar a diminuição expressiva do número de autos de infração emitidos pelo órgão em relação a crimes contra a flora da região. O Gráfico 2, a seguir, demonstra que embora a aplicação de multas tenha decrescido gradualmente desde 2009 (exceto entre 2012 e 2013), os percentuais de queda verificados foram sempre menos significativos que o de 2019. Nesse ano, o número de infrações foi 35,82\% inferior ao verificado no ano de $2018^{37}$.

Gráfico 2 - Variação nas infraç̃̃es aplicadas pelo Ibama em relação à flora na região da Amazônia Legal (2009-2019).

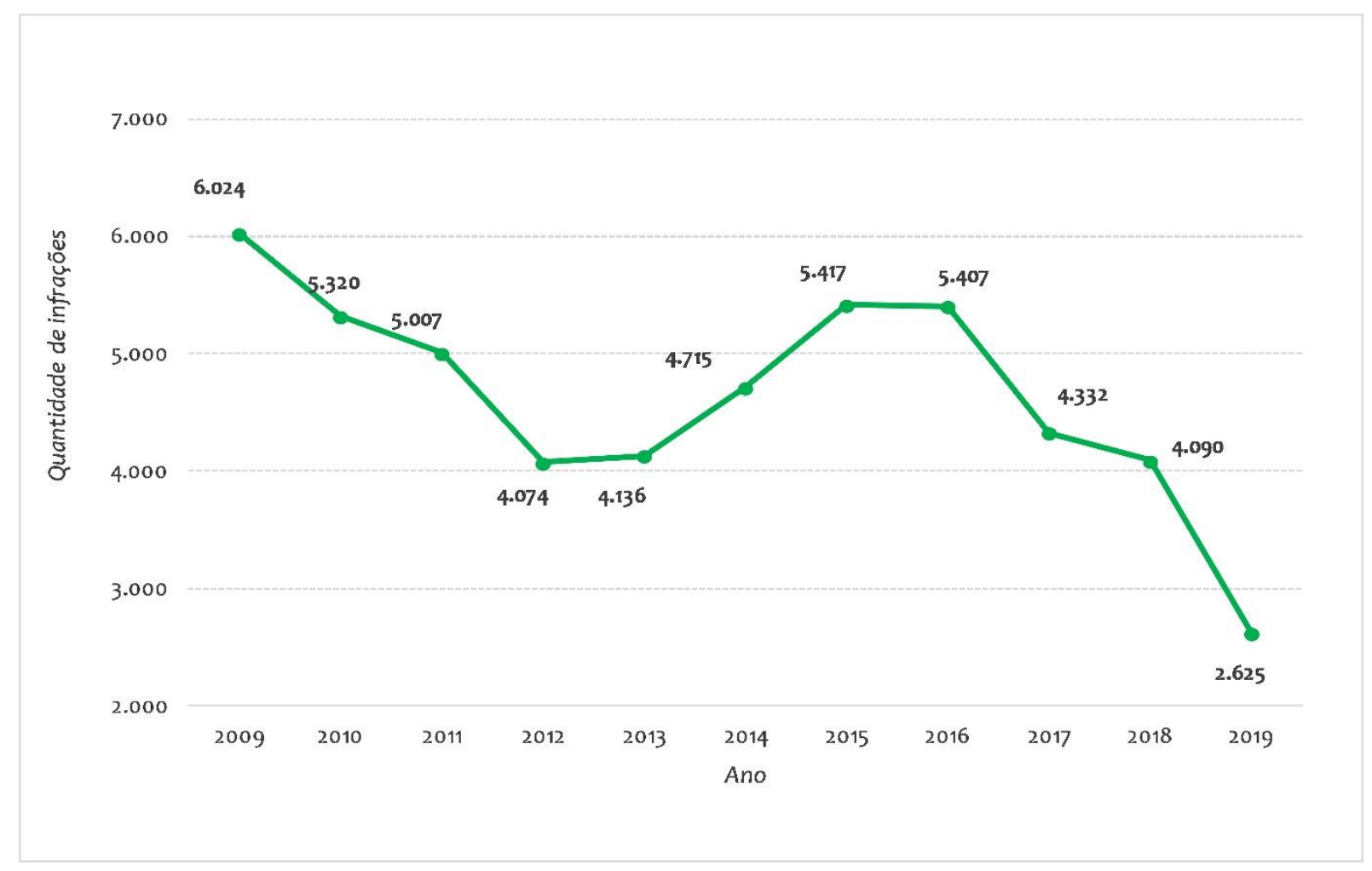

Fonte: IBAMA, 2019. Elaboração própria, 2020.

36 Consultar: https://noticias.band.uol.com.br/noticias/100000968927/ comamazoniaemchamasbolsonaroenfraquecepapeldoibama.html>. Acesso em 13/08/2020.

37 Conforme a notícia, houve queda de $23 \%$ da aplicação de infrações em relação ano de 2018 ainda nos primeiros seis meses do governo no ano de 2019. Disponível em: <https://www1.folha.uol.com.br/ambiente/2019/07/sobbolsonaro-multas-contra-desmatamento-caem-23.shtml>. Acesso em 04/09/2020. 
Os Gráficos 1 e 2 parecem indicar a correlação entre um evidente enfraquecimento institucional do Ibama (especialmente no que tange à sua capacidade fiscalizatória) e o crescimento das pressões antrópicas exercidas sobre o bioma amazônico. O que, a rigor, vinha sendo verificado desde 2012. Segundo relatos de analistas ambientais do Ibama ${ }^{38}$, desde 2019 a agência vem sofrendo um processo de esvaziamento e sucateamento que explicaria o arrefecimento de suas atividades e, portanto, do número de autos de infração relativos a crimes contra a flora, combinado com o avanço do desmatamento na região.

Diante do quadro que se desenhava já no primeiro ano da gestão de Ricardo Salles, apontando na direção de objetivos enunciados pelo Presidente quando ainda candidato, elaboramos algumas reflexões a respeito das decisões que vinham sendo tomadas desde os primeiros meses da nova administração. Em primeiro lugar, foi importante esclarecer se as mudanças promovidas pela gestão Salles poderiam ser compreendidas como "avanços" pontuais e episódicos, atribuíveis à permanente "queda de braço" entre, de um lado os interesses e ações preservacionistas e, de outro, os interesses e iniciativas "desenvolvimentistas" realizadas pelos agentes econômicos.

Uma segunda hipótese a ser considerada apontava para uma ação intencional e coordenada visando a alteração do sistema brasileiro de gestão ambiental ainda vigente. Nesse sentido, foi investigada também a origem das iniciativas e dos atos que sustentam as mudanças propostas e/ou efetivadas. Neste caso, consideramos relevante identificar se as iniciativas e atos eram originários do Poder Legislativo e, portanto, se eles respondiam às expectativas de um grupo político específico (ou mesmo de coalizões) e dos interesses por eles representados. Admitíamos também, como hipótese alternativa, tratarem-se de atos originários do comando central do Executivo, o que poderia significar uma

\footnotetext{
${ }^{38} \mathrm{Em}$ depoimento realizado no contexto da investigação sobre improbidade administrativa do Ministro Ricardo Salles, conduzido pelo Ministério Público Federal, o Coordenador Geral de Fiscalização Ambiental do Ibama (abr./2017 a abr./2020) indicou que a fiscalização ambiental do órgão vinha sofrendo pressões do governo para contenção de suas atividades. Disponível em: <https://oglobo.globo.com/sociedade/pressao-de-bolsonaro-sallesreduziu-fiscalizacao-ambiental-dizem-ex-coordenadores-do-ibama-24521565>. Acesso em 12/07/2020.
} 
ação não só centralizada, mas que decorreria de um verdadeiro "projeto de governo", de um plano de reformas que atenderia a grupos e agentes identificáveis.

Além destas questões, também consideramos importante quais temas e biomas vêm recebendo mais atenção nas alterações em curso, procurando evidenciar uma possível convergência de ações em direção à Região Amazônica. A quarta e última questão averiguada está centrada na intencionalidade e sistematicidade (ou não) das mudanças propostas/efetivadas. Questionou-se para tanto se as modificações em curso são direcionadas ao aparato normativo-legal, ou se estão combinadas com alterações no tocante às funções, estruturas e dinâmicas das instituições que alicerçam o funcionamento das políticas ambientais nacionais.

Para responder a essas questões foi feito o levantamento dos normativos publicados nos 15 (quinze) meses iniciais do governo de Jair Bolsonaro (janeiro 2019 a março 2020), buscando identificar as normas cujos efeitos atingiam, direta ou indiretamente, a estrutura e dinâmica do sistema brasileiro de gestão ambiental. Os atos normativos levantados totalizaram 942 normas, incluindo além de leis e decretos publicados no Diário Oficial da União, os Projetos de Leis (PLs) e Medidas Provisórias (MPs) não convertidas em leis. Tais normas foram sistematizadas em um banco de dados que subsidiaram as análises sobre o Gráfico 3, adiante.

O primeiro destaque a ser feito diz respeito a que 60 do total de 942 atos (cerca de $6 \%$ das normas publicadas nesse período) tratarem de temas diretamente associados à agenda ambiental. Além do número mais expressivo verificado no governo Bolsonaro, preocupa também o fato de que, das 60 normas associadas à matéria ambiental, 53 (88\%) corresponderam a iniciativas do Poder Executivo. A ação majoritariamente centralizada na alta administração do novo governo é um indicativo de que elas parecem compor parte de uma estratégia do governo em relação à matéria específica. A análise das 60 normas editadas entre janeiro/2019 a março/2020 indicou que tais atos normativos integrariam uma ação objetiva e coordenada visando a flexibilização de regras, ritos e estru- 
turas, conforme poderemos oferecer mais detalhes adiante. A consulta a essa base indicou que os temas alvo de alterações foram tratados sempre no sentido de reverter tendências ou retroceder o que se tinha como avanços no trato das diferentes temáticas ambientais.

Outro ponto substancial refere-se à identificação das temáticas mais frequentes. Identificamos retrocessos, já mencionados, na agenda de Mudança do Clima envolvendo alterações em fundos e comissões, incluindo a exclusão da participação de representações das organizações civis. Modificações também foram introduzidas na composição e funcionamento de comissões e fundos que tratavam de outras temáticas tais como flora, Amazônia, recursos hídricos e o próprio CONAMA. Em vários casos, tais comissões passaram a ter caráter meramente consultivo, o que acaba sendo redundante face a eliminação do caráter paritário e diversificado de suas plenárias.

No Gráfico 3, a seguir, são apresentadas as principais temáticas tratadas pelo conjunto das normas analisadas.

Gráfico 3 - Temas das normas com matéria ambiental publicadas no período janeiro/2019-março/2020.

Conselhos, Comissỏes e Fundos ambientais

Fauna
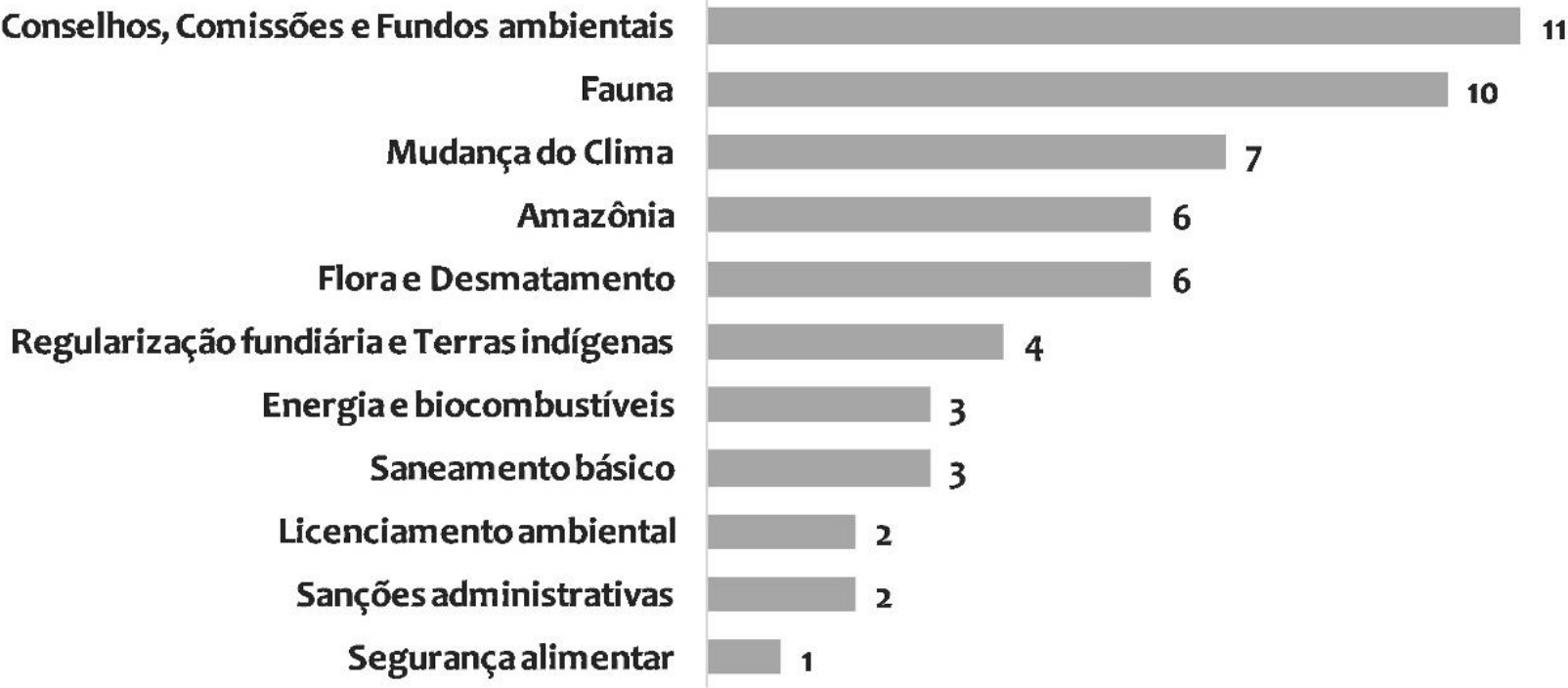

Fonte: Planalto Central, 2020. Elaboração própria, 2020. 
Além das categorias indicadas no Gráfico 3, cabe destacar que também identificamos uma norma que tratou do Programa de Proteção aos Defensores de Direitos Humanos, Comunicadores e Ambientalistas, bem como de Conselho Deliberativo com a mesma finalidade ${ }^{39}$, e quatro normas cujo objetivo foi fazer uma gestão do estoque regulatório existente, em que cada um destes decretos instituiu a revogação de centenas de outros decretos, dentre os quais, diversas normas cujo tema tinha relação com a matéria ambiental ${ }^{40}$.

Conforme pode ser observado no Gráfico 3, a revisão de "Conselhos, Comissões e Fundos ambientais" foi a temática que concentrou maiores esforços no sentido tanto de modificar o seu funcionamento, como visando diminuir seu tamanho e a representatividade da sociedade civil nestes espaços. Além do CONAMA, cuja composição foi reduzida de 96 para 23 membros, sofreram alterações também diversos conselhos temáticos como os Conselhos Nacionais dos Recursos Hídricos, Biodiversidade, Amazônia e Clima. Em geral, as modificações visaram diminuir o número de seus membros, na intenção de reduzir a participação e representatividade da sociedade civil nesses fóruns e forma de (re) centralizar as decisões nas mãos das autarquias públicas, sobretudo, nos Ministérios. O CONAMA vinha sendo considerado como um fórum de gestão democrática e participativa aplicada à matéria ambiental. A sua composição atual reduziu ainda mais a representatividade das organizações não governamentais, concentrando o poder nas mãos do setor público, questão que já vinha sendo alvo de críticas, conforme assinalaram Bursztyn e Bursztyn (2012) e Moura e Fonseca (2016).

O tema "Fauna" concentrou o segundo número absoluto de normas, tendo a maior parte delas tratado da regulamentação de produtos de origem animal, chamando

\footnotetext{
39 O Decreto n 9.937/2019 vai na “contramão" das demais normas, ampliando as atribuições do Programa de Proteção aos Defensores de Direitos Humanos, Comunicadores e Ambientalistas (PPDDH), criado originalmente pelo Decreto $n^{\circ}$ 9.937/2016, cujo intuito é articular medidas para a proteção de pessoas ameaçadas em decorrência de sua atuação na defesa dos direitos humanos.

40 Dado o fôlego desta pesquisa, não foi possível identificar todas as normas revogadas por tais decretos. Para maiores informações, sobre quais normas foram revogadas e os assuntos tratados por cada delas, sugerimos consulta aos Decreto n 10.179/2019; Decreto n 10.087/2019; Decreto $n^{\circ}$ 10.086/2019 e $n^{\circ}$ 10.223/2020.
} 
atenção a instituição do Dia Nacional do Rodeio. Contudo, deve ser destacada a convergência das normas que deverão interferir negativamente sobre o bioma Amazônia. Somando-se as normas referidas a "Mudança do Clima", "Flora e Desmatamento", "Regularização Fundiária e Terras Indígenas" e "Amazônia" chegamos ao total de 23 (ou 38\%) das 60 normas editadas com relação a matéria ambiental. Isso denota um alvo preferencial inegável, ainda mais se considerarmos que, em sua maioria, tais normas tendem a rever formatos, funções e dinâmicas tidas como positivas e consolidadas pelo movimento ambientalista.

A agenda de Mudança do Clima foi alvo de muitas alterações, especialmente no que se refere à composição de comissões e comitês relacionados à temática. Além disso, também merece ser ressaltado o fato de que três (3) normas relacionadas ao tema foram publicadas às vésperas da reunião da COP-25, ocorrida na Espanha entre 02 a 13 de dezembro de 2019:

(i) o Decreto $n^{\circ}$ 10.143/2019, introduziu alterações no Fundo Nacional sobre Mudança do Clima e na Política Nacional sobre Mudança do Clima que restringiram a representação de setores não governamentais no Comitê Gestor do Fundo às Confederações Nacionais, excluindo a possibilidade de representação de ONGs e da comunidade científica;

(ii) o Decreto $n^{\circ}$ 10.144/2019, que modifica a Comissão Nacional para Redução das Emissões de Gases de Efeito Estufa Provenientes do Desmatamento e da Degradação Florestal, Conservação dos Estoques de Carbono Florestal, Manejo Sustentável de Florestas e Aumento de Estoques de Carbono Florestal - REDD+ (CONAREDD+). A criação da Comissão, em 2015, já havia sido questionada face à ausência de debates junto à sociedade civil, assim como pela limitação da representação das organizações civis a apenas duas (2) cadeiras, enquanto o poder público contava com oito (8) representações. A versão atual limitou ainda mais a 
representação da sociedade civil, restringindo-a a uma (1) vaga, além de ter enxugado a sua composição total de dez (10) para sete (7) representantes; e (iii) o Decreto nº 10.145/2019, que dispõe sobre o Comitê Interministerial sobre Mudança do Clima, que substituiu a Comissão Interministerial criada em $1999^{41}$ também merece anotações. O novo Comitê deixou de ter a antiga atribuição para apreciar projetos que resultem em redução de emissões e que sejam considerados elegíveis para o Mecanismo de Desenvolvimento Limpo (MDL). Além disso, houve uma recomposição do seu plenário em função das mudanças e fusões no tocante aos ministérios no governo Bolsonaro, o que resultou num Comitê "mais enxuto", passando de onze (11) para oito (8) representantes ministeriais.

Ainda que o Brasil tenha permanecido como signatário do Acordo de Paris, os atos normativos consultados ratificam o enfraquecimento das instâncias de governança que possibilitariam guardar os compromissos assumidos pelo país ${ }^{42}$. Além da redução da participação da sociedade civil em conselhos na área ambiental, também merece atenção o corte de $95 \%$ do orçamento do MMA referente a componentes das mudanças climáticas $^{43}$. Importante mencionar que o corte orçamentário também foi direcionado a outras pastas e instituições vinculadas à agenda ambiental, conforme reunido no documento organizado pela ASCEMA (2020), podendo também ser citado o IBAMA, que teve corte orçamentário em diversas de suas atribuições ${ }^{44}$ e o ICMBio que teve redução de $26 \%$ do orçamento destinado a gestão, manutenção e implementação de Unidades de Conservação federais em $2019^{45}$.

\footnotetext{
${ }^{41}$ Criada pelo Decreto de 07 de julho de 1999, foi revogada pelo Decreto $n^{\circ} 10.223 / 2020$.

42 O Brasil ratificou seu compromisso em restaurar, reflorestar e promover a regeneração de doze milhões de hectares de florestas até 2030.

43 Foram bloqueados 95\% dos $\mathrm{R} \$ 11,8$ milhões disponíveis para as políticas sobre mudanças climáticas. Notícia disponível em: <https://oglobo.globo.com/sociedade/ministerio-do-meio-ambiente-bloqueia-95-da-verba-paraclima-23646502>. Acesso em 18/08/2020.

44 Disponível em: <https://politica.estadao.com.br/noticias/geral,ministro-ricardo-salles-manda-cortar-24-doorcamento-do-ibama,70002806082>. Acesso em 09/09/2020.

45 Disponível em: <https://www.oeco.org.br/noticias/governo-corta-r-187-milhoes-do-mma-saiba-como-o-corte-foidividido/>. Acesso em 09/09/2020.
} 
Quanto à temática “Flora e Desmatamento", sobressaem dois aspectos: (i) da mesma forma que em relação a outras temáticas aplicou-se também, nesse caso, a regra de alterar conselhos, comissões e fundos que tratam do tema; e (ii) as alterações quanto às hipóteses sobre o emprego de fogo. Quanto à primeira, cabe destaque para o fato de que no lugar da Comissão Nacional para a Recuperação da Vegetação Nativa foi criada a Comissão Executiva para Controle do Desmatamento Ilegal e Recuperação da Vegetação Nativa, constituída apenas por representantes ministeriais, admitindo convidados como especialistas e representantes de órgãos e entidades públicas e privadas da sociedade civil, sem terem, no entanto, direito a voto. A Comissão anterior, além de contar com representantes indicados pela Associação Brasileira de Entidades Estaduais de Meio Ambiente (ABEMA) e a das municipais (ANANMA), também previa a representação de dois representantes da sociedade civil.

Quanto à temática do emprego de fogo foram publicados dois decretos em agosto de 2019 como resposta à ocorrência de intensas queimadas na região amazônica. Cunhou-se à época o codinome "Dia do fogo" 46 para fazer referência a ato cujos reflexos também atingiram cidades localizadas em outras regiões, como a Sudeste e a Sul ${ }^{47}$. Os decretos trataram das hipóteses em que deveriam ser suspensas as permissões para o emprego de fogo. É sintomático, nesse caso, o fato de que eles tenham excluído da suspensão as práticas agrícolas fora da Amazônia Legal. Além disso, diversas críticas trataram das respostas dadas pelo governo ao episódio, pois não houve nenhuma ação coordenada e sistêmica para responder à questão. Como respostas governamentais foram editados decretos de Garantia da Lei e da Ordem (GLO), notadamente, ações pontuais. Outro aspecto sintomático da incipiência de respostas governamentais ao evento, foi o fato do Grupo Especial de Fiscalização (GEF) do Ibama não ter sido acionado ${ }^{48}$. Também merece ser citado o Decreto $n^{\circ} 10.235 / 2020$, que alterou a natureza da Comissão Nacional

\footnotetext{
${ }^{46}$ Disponível em: <https://www.brasildefato.com.br/2019/08/15/estimulados-por-bolsonaro-fazendeiros-promovemdia-do-fogo-na-amazonia/>. Acesso em 09/09/2020.

47 Disponível em: <https://g1.globo.com/natureza/noticia/2019/09/19/fumaca-de-queimadas-na-amazonia-e-empaises-vizinhos-chega-aos-ceus-do-sul-e-do-sudeste-do-brasil.ghtml>. Acesso em 08/05/2020.

${ }^{48}$ Disponível em: <https://www.bbc.com/portuguese/brasil-49430376>. Acesso em 09/09/2020.
} 
de Biodiversidade, que tinha caráter deliberativo e passou à condição de um fórum de natureza apenas consultiva. Além disso, sua composição também foi alterada, do que resultou a redução do número de representantes, tendo sido excluídas as participações do Ibama, ABEMA, assim como o prejuízo da participação de especialistas e organizações sociais, que antes possuíam oito (8) cadeiras, passando a ficar restritas a duas (2) representações ${ }^{49}$. Chama atenção também o fato de a representação indígena não fazer parte da plenária dessa Comissão, assim como da Comissão ter perdido a atribuição de "aprovar a metodologia para elaboração e o texto final dos relatórios nacionais para a Convenção sobre Diversidade Biológica".

As alterações no tocante ao "Fundo Nacional de Desenvolvimento Florestal" também merecem atenção. O Fundo passou a ser gerido por uma Comissão sem participação social, diferente da composição anterior que previa representantes indicados pelo Fórum Brasileiro de Organizações Não Governamentais e Movimentos Sociais para o Meio Ambiente e Desenvolvimento ${ }^{50}$.

Em relação às normas referentes especificamente à Amazônia (em número de 6 ou 10\% do total de normas ambientais), todas trataram da (re) composição de conselhos e fundos. Foram objeto de alteração o Conselho Nacional da Amazônia Legal, o Conselho Deliberativo do Sistema de Proteção da Amazônia e o Comitê do Programa de Áreas Protegidas da Amazônia (ARPA). Além destas, o Fundo de Desenvolvimento da Amazônia também sofreu alteração. Dentre as modificações trazidas, chamamos atenção para o Conselho Nacional da Amazônia Legal, cujas atribuições incluem a coordenação de ações governamentais na Amazônia Legal, bem como ações de prevenção e fiscalização na região, que foi transferido do Ministério do Meio Ambiente para a Vice-Presidência da República. Em sua nova composição, foi excluída a representação dos governadores dos

\footnotetext{
49 Sendo uma para universidade ou instituto de pesquisa que seja especialista na área de biodiversidade e a outra para entidade ambientalista de âmbito nacional inscrita há, no mínimo, um ano no Cadastro Nacional de Entidades Ambientalistas (CNEA).

${ }^{50}$ Incluindo os seguintes segmentos: a) movimentos sociais; b) organizações ambientalistas; e c) comunidades tradicionais.
} 
estados da região, passando a integrá-lo apenas os representantes ministeriais e de secretarias de governo. Além disso, 19 militares e quatro (4) delegados foram nomeados para as quatro comissões temáticas que o integram, destacando-se, portanto, a ausência de representantes do Ibama, vinculado ao MMA, e da Funai, vinculada ao Ministério da Justiça e de especialistas.

A diminuição do aparato para a contenção do desmatamento, somado aos rumores de que o governo estuda alterar as normas sobre as permissões do uso dos recursos do Fundo Amazônia (FA), tem repercutido sob a forma de estranhamentos diplomáticos entre o Brasil e os principais investidores do FA, Alemanha e Noruega. Os investidores alegaram discordar das modificações que vêm sendo pretendidas pelo governo, como a permissão de que os recursos do FA sejam destinados a indenizações a donos de propriedades privadas em áreas de unidades de conservaçãa ${ }^{51}$. As declarações e decisões acerca da política de contenção do desmatamento na Amazônia têm colocado o Brasil em uma situação de desconforto em relação ao cenário econômico mundial, já que além dos tradicionais compradores (países europeus) da cadeia produtiva de grãos-carne, também os novos (como a China) vêm demonstrando insatisfação sobre as políticas adotadas. Posições como essas reforçam as reflexões sobre como a matéria ambiental sempre esteve sujeita às pressões internacionais e como tais questões são conduzidas internamente. As declarações oficiais de alguns países europeus (como Bélgica e França, por exemplo), de que não aprovarão o acordo entre a Comunidade Europeia e o Mercosul por causa das políticas ambientais brasileiras, alinham-se nessa mesma direção.

A respeito das normas e as propostas em torno do tema das "Regularização fundiária e Terras Indígenas (TI)", elas têm em comum a convergência de interesse sobre a exploração das terras da Amazônia, flexibilizando as regras vigentes, na linha do que foi proposto na $\mathrm{PEC} \mathrm{n}^{\circ} 215 / 2000$ já mencionada. Dentre as proposituras, destaca-se a contida na MP n 910/2019, que ficou popularmente conhecida como "MP da grilagem", que por

\footnotetext{
${ }^{51}$ Notícia disponível em: <https://g1.globo.com/politica/noticia/2019/05/25/governo-estuda-usar-fundo-amazoniapara-indenizar-desapropriacoes-de-terra.ghtml>. Acesso em 10/07/2020.
} 
perder sua validade, foi substituída pelo Projeto de Lei $\mathrm{n}^{\circ} 2.633 / 2020^{52}$. Dentre os pontos polêmicos do PL estão a propositura de um "processo simplificado" de regularização de terras referentes até seis (6) módulos fiscais ocupados até julho de 2008, dispensandose a vistoria prévia pelo Incra, sendo que o processo poderá ser realizado usando-se apenas dos recursos de sensoriamento remoto. Além destes, o Projeto de Lei no 191/202053, que tem como intuito possibilitar a realização de atividades mineradoras em terras indígenas, também merece atenção, já que propõe que o Presidente possa encaminhar pedidos de autorização da realização de atividades mineradoras em terras indígenas ao Congresso Nacional, mesmo que as comunidades indígenas afetadas se manifestem contrariamente, conforme art. $14, \S 2^{\circ}$ do PL.

A propósito da capacidade de resposta das agências ambientais, especialmente em situações de contingência, é emblemático o episódio de derramamento de óleo ocorrido em agosto de 2019, que atingiu uma boa parte do litoral brasileiro ${ }^{54}$. A resposta ao incidente envolveu a seguinte avaliação por parte da WWF55:

O Governo Federal demorou para agir e não acionou o Plano Nacional de Contingência de Incidentes com Óleo (PNC). O Ministro do Meio Ambiente, Ricardo Salles, fez sua primeira menção ao caso mais de um mês depois dos primeiros registros de manchas de óleo e a mancha já se espaIhava há quase 40 dias quando o governo iniciou investigações sobre as causas da tragédia.

A hipótese de um "projeto" coordenado e intencional de desconstrução do sistema nacional de gestão ambiental sai fortalecida face à combinação de modificações introduzidas no arcabouço legal e das instituições que dão estrutura e dinâmica à Política

\footnotetext{
${ }^{52}$ Em consulta realizada em 25 jul. 2020 sobre a situação da tramitação do PL, este aguardava apreciação das comissões.

53 Em consulta realizada em 25 jul. 2020 sobre a situação da tramitação do PL, este aguardava apreciação das comissões.

54 Em dezembro de 2019, as estimativas disponíveis davam conta de 877 locais atingidos em mais de 127 municípios em 11 estados em uma área total superior a 3 mil quilômetros.

55 Disponível em: <wwf.org.br>. Acesso em 24/10/2020.
} 
Ambiental. Às alterações das estruturas/composição/funcionamento dos fóruns colegiados afeitos às políticas ambientais, somam-se relevantes modificações nas estruturas e competências das instituições em âmbito federal e regional. Intensas mudanças foram feitas nos ocupantes de cargos comissionados do MMA, Incra e ICMBio, muitas vezes substituídos por profissionais de fora da carreira, carentes de experiência na matéria específica, chamando a atenção o número destes que têm origem nos quadros do Exército Brasileiro e das polícias militares. Assim, o cenário a ser considerado é que, embora a estrutura do SISNAMA, proposto pela PNMA (1981), não tenha sido formalmente alterada, as modificações realizadas em termos da lógica de funcionamento e composição das instituições que o estruturam vêm exercendo papel análogo (ou ainda mais consistente) em termos de uma efetiva desestruturação do sistema. Sobretudo, porque são estas instituições que estruturam e viabilizam a continuidade da proteção à natureza no contexto nacional.

Enfim, as decisões veiculadas através de portarias e resoluções internas às diferentes autarquias produzem efeitos importantes tais como cortes e contingenciamentos de orçamentos, movimentação e (não) reposição de pessoal, cancelamento de contratos de serviços de terceiros. Essas medidas situadas no plano infralegal e que não foram analisadas nesse trabalho, compõem parte importante das formas de garroteamento das instituições e suas práticas. A polêmica sobre a extinção do Ministério do Meio Ambiente consistiu em um "cartão de visitas" apresentado antes das eleições. Pelo que se vê, ela prenunciava a real política ambiental do novo governo.

\section{Considerações Finais}

A primeira consideração a ser feita diz respeito ao fato desse texto ter sido intencionalmente composto em duas partes. Na primeira, elaborada com base em registros 
bibliográficos, destacamos elementos considerados relevantes face às políticas ambientais praticadas no período 1970-2010. Com eles, compusemos uma linha do tempo que é desdobrada em fases. Na segunda parte, tendo por base uma consulta a fontes oficiais, elaboramos uma análise mais interpretativa das mudanças normativas introduzidas no sistema brasileiro de gestão ambiental na década 2010-2020, mais especificamente no último biênio desta.

Ficou evidente a existência de um momento de ruptura na trajetória dessas políticas e, consequentemente, de uma certa crise de desempenho do sistema brasileiro de gestão ambiental. Arbitramos que essa ruptura ganhou corpo no início da década de 2010, a partir de quando começa uma transição entre dois modelos. O primeiro construído ao longo do período 1970/2010 e o segundo que resulta de sua desconstrução, tendo como uma das referências iniciais a promulgação da Lei nº 12.651/2012 (novo Código Florestal).

Essa transição é marcada por mudanças importantes na regulação ambiental, nas diretrizes políticas e na institucionalidade do sistema, assim como na disponibilidade de recursos humanos-financeiros-materiais por parte das agências ambientais e suas redes. Dentro dessa nova trajetória, o sistema vai sendo transformado e esvaziado segundo um ideário em que prevalece o "menos Estado" (ou "mais mercado") e a abordagem da questão ambiental segundo uma ótica antipreservacionista e privatista. Destaque-se que, esse processo de desconstrução, vem ocorrendo em um ambiente de decisões centralizadas e ausência de diálogo entre as partes interessadas.

Verifica-se que, a partir do golpe ou impedimento da Presidente Dilma (2016) e particularmente da posse do Governo Bolsonaro (janeiro de 2019, esse processo de desconstrução aparenta ter ganhado sistematicidade, intencionalidade e coordenação. Conforme indicamos, destacam-se três pilares principais: (i) as expressivas alterações no aparato normativo-legal que estrutura e orienta o funcionamento do sistema brasileiro de 
gestão ambiental; (ii) as alterações na lógica de operação das instituições que materializam o funcionamento do sistema ${ }^{56}$ e o desprestígio com que são tratadas; assim como suas equipes; e (iii) o garroteamento de atividades basilares (de fiscalização, por exemplo) que vai comprometer a capacidade de (re)ação do sistema, contribuindo também para as lamentáveis respostas às tragédias ambientais com derramamentos de óleo (faixa litorânea das regiões Norte, Nordeste e Sudeste), rompimentos de barragens de rejeitos (Brumadinho, Minas Gerais) e os incêndios florestais (no Pantanal, Amazônia e (entro-Oeste) experimentados recentemente.

O pronunciamento feito pelo ministro do MMA, Ricardo Salles, em reunião ministerial de 22.04.2020 traduz, num linguajar rasteiro e impróprio, o que parece ser a narrativa oficial da atual administração federal. Conforme registrado pelo O Globo, no mesmo mês em que o desmatamento na Amazônia e as queimadas no Pantanal batem recordes históricos, o ministro resumiu assim, para o Presidente e seu ministério, os objetivos estratégicos no tocante à sua pasta: "Então para isso precisa ter um esforço nosso aqui enquanto estamos nesse momento de tranquilidade no aspecto de cobertura de imprensa, porque só fala de Covid, e ir passando a boiada e mudando todo o regramento e simplificando normas" (O GLOBO, 23.05.2020, p.12).

Anteriormente à ruptura a que nos referimos (centrada, digamos, no ano de 20122016), predominavam mudanças normativas de caráter pontual (seja do ponto de vista temático, espacial ou temporal), geralmente defendidas ou promovidas por associações comerciais e entidades das classes produtoras. Embora contassem com algum apoio da alta administração pública, essas mudanças guardavam relação direta com alianças e representações específicas que trabalhavam, por exemplo, em favor da flexibilização de determinadas normas ou do abrandamento da ação dos controles públicos sobre um determinado setor.

\footnotetext{
${ }_{56}$ Podemos destacar duas alterações importantes neste tocante: a modificação na lógica de funcionamento do ICMBio, que a partir do Decreto $n^{\circ} 10.234 / 2020$ passou a funcionar a partir de cinco gerências correspondentes às macrorregiões do país, na estrutura anterior, sua divisão era assentada a partir de onze gerências regionais; e a ressubordinação da ANA e do CNRH ao MDR, indicando o novo arranjo institucional segundo o qual as políticas hídricas passaram a ser conduzidas.
} 
A partir de 2012 e, sobretudo no ano de 2018, durante a campanha eleitoral de Jair Bolsonaro, cujas aspirações vieram a se confirmar com a sua eleição em janeiro de 2019, o debate deixou de estar limitado a pontos ou agendas isoladas. Fazendo aqui um paralelo muito comum no país do futebol, diríamos que os debates deixaram de se limitar aos resultados de um jogo específico e passaram a focar mudanças gerais nas regras de todos os jogos, assim como do formato de todos os campeonatos. Passou-se de forma gradual mas, conforme dito, de forma intencional, sistemática e coordenada - a colocar em questão o sistema em sua integralidade. A defesa dessas mudanças foi motivo de uma coalizão formada pelas clássicas associações comerciais e entidades de classes produtoras e bancadas parlamentares que apoiavam diferentes bandeiras ${ }^{57}$. Unida em torno de interesses convergentes, essa coalizão apoiava candidatos às eleições majoritárias de 2018, inclusive a presidencial.

Caso estejamos corretos nessa interpretação, parece admissível afirmar que a Ricardo Salles teria sido incumbida a missão de coordenar as ações visando à desconstrução do sistema ambiental federal. Essa desconstrução não é, portanto, consequência de ações isoladas, desconexas ou simplesmente alucinadas. Ao contrário, essas ações formariam parte de um conjunto estruturado, cuja origem é o próprio Poder Executivo e não o MMA. Projetando-se no tempo a forma de condução (centralizada e autoritária) e a celeridade das decisões (ver o número e impacto das decisões tomadas nos quinze primeiros meses de governo), teremos um cenário ainda mais preocupante para os dois anos que restam ao atual governo.

Parece-nos sintomático que a desconstrução tenha focado prioritariamente nos vários fóruns onde são (ou eram) debatidas e avaliadas as políticas ambientais mais sensíveis. Transparência e participação eram tidas até bem pouco tempo como avanços irrecorríveis. Contudo, em dois anos, vários destes fóruns perderam a condição de colegiados com caráter deliberativo, além de terem tido eliminadas (ou restringidas de forma

\footnotetext{
${ }^{57}$ Muito se fala sobre a "bancada BBB" cujos membros representariam interesses vinculados ao "Boi" (indicando relações com o agronegócio e madeireiros), à "Bala" (indicando relações com forças de segurança e indústria/comércio de armamento) e à "Bíblia" (indicando relações com igrejas pentecostais e neopentecostais).
} 
radical) a presença das organizações civis, da academia e até mesmo das agências ambientais essenciais (Funai, Ibama, ICMBio etc.).

Exemplos emblemáticos são os colegiados vinculados às agendas das Mudanças Climáticas e da Proteção das Florestas, intimamente conectadas com o bioma Amazônia, que foram objeto de alterações das mais profundas. Mudanças que certamente gerarão dificuldades no cumprimento dos compromissos assumidos no Acordo de Paris e que apontam também para efeitos relevantes sobre a condição brasileira no cenário internacional, seja como liderança ou negociador. Como alerta, bastaria lembrar que as negociações relativas ao acordo comercial União Europeia - Mercosul (2020), envolvendo países que movimentam $25 \%$ do PIB mundial, encontram-se na geladeira por conta de críticas de países como a Bélgica e França às políticas ambientais do governo brasileiro, especialmente em relação à Amazônia.

Finalizando, queremos lembrar que nossa intenção nunca foi a de esgotar as inúmeras temáticas aqui ventiladas. Tanto é assim que boa parte do trabalho se limitou à montagem de uma linha do tempo das políticas consideradas relevantes no período 19702010. A outra parte, de caráter mais analítico (ou interpretativo), também não passa de uma listagem de temas para aprofundamento por parte dos eventuais interessados. E vale chamar a atenção que, nessa parte, ocupamo-nos somente das decisões que alcançam ser tratadas em Decretos, Projetos de Leis e Projetos de Emenda Constitucional. Além desses diplomas de ordem superior, há um incontável número de normas infralegais (tais como portarias e deliberações internas dos órgãos da administração direta e autarquias) que ajudariam a resgatar o cotidiano das instituições, e que nos levariam a entender a real política que está sendo implementada - isso fica como sugestão também.

Aos estudantes de Geografia, esperamos ter contribuído para despertar o interesse por uma variedade de objetos pesquisa ou, pelo menos, com um elenco de provocações que possam levá-los a definir seus próprios interesses. A quem interessar, recomendamos que procurem evitar abordagens fragmentárias, muito em uso nos dias de hoje, inclusive na própria Geografia. Outra indicação que nos parece conveniente, que 
encontra na Geografia e nas discussões sobre o ordenamento territorial um campo fértil, se refere aos instrumentos de planejamento e gestão territorial, tais como Planos de Bacia Hidrográficas, Zoneamentos Ecológicos-Econômicos (ZEE), Zoneamento Costeiro e Avaliações Ambientais Estratégicas (AAE). As experiências acumuladas nessas matérias são, salvo raríssimas exceções, muito frustrantes. Sobretudo no que se refere aos resultados práticos obtidos em termos de prevenção e controle efetivo das formas de degradação do ambiente. Quem duvidar disso, basta lembrar quantas vezes esses instrumentos foram mencionados quando da ocorrência de tragédias ambientais recentes como as queimadas no Pantanal e Amazônia, o rompimento de barragens de rejeitos da mineração em Minas Gerais ou o derramamento de petróleo ao longo da costa brasileira. Do ponto de vista teórico-metodológico, recomendamos que abusem dos enfoques que favoreçam olhares transversais sobre o binômio sociedade-natureza. Visões compartimentadas já mostraram até onde podem contribuir. No mesmo sentido, recomendamos que procurem familiarizar-se com as propostas da Geografia Ambiental, assim como prestigiar as contribuições e o engajamento inspirados na Ecologia Política.

\section{Agradecimentos}

Gostaríamos de expressar nossos profundos agradecimentos à cuidadosa leitura realizada pelo professor Cláudio Egler, que nos permitiu não apenas amadurecer as reflexões que integram o estudo, mas também reorganizar o documento como um todo. Também agradecemos a Pedro Della Vedova e Paula Serrano do Carmo por terem encontrado tempo, em meio aos seus muitos afazeres, para nos ajudar lendo e comentando o trabaIho. Aos alunos da disciplina "Tópicos Especiais em Gestão Ambiental: Grandes projetos" oferecida no Departamento de Geografia da UFRJ no segundo semestre de 2020, agradecemos igualmente pela possibilidade de apresentar e discutir o levantamento empírico 
realizado neste estudo, em que os questionamentos e debates suscitados pelos discentes foram de fundamental importância para o aperfeiçoamento das análises.

\section{Referências}

AB'SÁBER, Aziz N. Previsão de impactos ambientais nos projetos de usinas hidroelétricas na Amazônia Brasileira. InterFacies, n 40, pp. 1-18, 1980.

AB’SÁBER, Aziz N. Amazônia: do Discurso à Práxis, São Paulo: EDUSP, 1997.

ASSOCIAÇÃO BRASILEIRA DE ENTIDADES ESTADUAIS DE MEIO AMBIENTE (ABEMA). Novas propostas para o licenciamento ambiental no Brasil. Associação Brasileira de Entidades Estaduais de Meio Ambiente; CARVALHO, José Carlos (org.) Brasília: ABEMA, 2013.

ASSOCIAÇÃO NACIONAL DOS SERVIDORES DE MEIO AMBIENTE (ASCEMA). Cronologia de um desastre anunciado: Ações do Governo Bolsonaro para desmontar as políticas de Meio Ambiente no Brasil. ASCEMA NACIONAL. Disponível em: <https://static.poder360.com.br/2020/09/Dossie_Meio-Ambiente_Governo-Bolsonaro_revisado_02-set-2020-1.pdf>. Acesso em 07/09/2020.

BARROS, Dalmo A.; BORGES, Luís A. C.; NASCIMENTO, Gleisson O.; PEREIRA, José A. A.; REZENDE, José L. P.; SILVA, Rossi A. Breve análise dos instrumentos da política de gestão ambiental brasileira. Política e Sociedade, v. 11, nº 22, pp. 155-179, 2012.

BECKER, Bertha K. Geopolítica da Amazônia. A Nova Fronteira de Recursos. Rio de Janeiro: Zahar Ed., 1982.

BECKER, Bertha K. (org.). Logística e Ordenamento Territorial. Relatório preparado como subsídio à elaboração da Política Nacional de Ordenamento Territorial (PNOT), 2006.

BECKER, Bertha K.; EGLER, Claudio. Detalhamento da metodologia para execução do zoneamento ecológico econômico pelos estados da Amazônia. Rio de Janeiro: SAESecretaria de Assuntos Estratégicos/Ministério do Meio Ambiente. 1997.

BURSZTYN, Maria A.; BURSZTYN, Marcel. Fundamentos de Política e Gestão Ambiental: caminhos para a sustentabilidade. Rio de Janeiro: Garamond. 2012. 
CÂMARA, João B. D. Governança ambiental no Brasil: Ecos do passado. Revista de Sociologia e Política, v. 21, nº 46, pp. 125-146, 2013.

CARVALHO, Fernanda V. de. The Brazilian position on forests and climate change from 1997 to 2012: from veto to proposition. Revista Brasileira de Política internacional, v. 55, pp. 144-169, 2012.

CASTRO, Edna (org.). Pensamento crítico latino-americano. São Paulo: Annablume, 2019.

COELHO, Maria Célia Nunes. 10 anos da Estrada de Ferro Carajás. Belém: UFPA, 1997.

COELHO, Maria C. N.; CUNHA, Luiz H. Política e Gestão Ambiental. In: CUNHA, Sandra; GUERRA, Antônio J. T. (orgs.). A questão ambiental: diferentes abordagens. Rio de Janeiro: Bertrand Brasil, 2005, p. 43-79.

DRUMMOND, José A. Por que estudar a história ambiental do Brasil? - ensaio temático. Varia História, v. 26, pp. 13-32, 2002.

DRUMMOND, José A.; BARROS-PLATIAU, Ana F. Brazilian Environmental Laws and Policies, 1934-2002: A critical overview. Law \& Policy, v. 28, nº 1, pp. 83-108, 2006.

FEARNSIDE, Phillip M. Conservation. Brazilian politics threaten environmental policies. Science, v. 353, nº 6301, pp. 746-748, 2016.

FEARNSIDE, Phillip M. O Desmonte da Legislação Ambiental. In: WEISS, Joseph S. (org.). Movimentos socioambientais: lutas: avanços: conquistas: retrocessos. Formosa: Xapuri Socioambiental, 2019. p. 317-382.

FERREIRA, Marcus B. M.; SALLES, Alexandre O. T. Política ambiental brasileira: análise histórico-institucionalista das principais abordagens estratégicas. Revista de Economia, v. 43, $n^{\circ}$ 2, pp. 1-17, 2016.

FRANCO, José L. A.; DRUMMOND, José A. O cuidado da natureza: a Fundação Brasileira para a Conservação da Natureza e a experiência conservacionista no Brasil: 19581992. Textos de História, v. 17, n 1 , pp. 59-84, 2009.

GUSMÃO, Paulo P. de; PAVÃO, Bianca B. M. Gestão das águas, comitês de bacias hidrográficas e resolução de conflitos ambientais. AMBIENTES: Revista de Geografia e Ecologia Política, v. 2, n² 2, pp. 38-77, 2019. 
INSTITUTO BRASILEIRO DO MEIO AMBIENTE E DOS RECURSOS NATURAIS RENOVÁVEIS (IBAMA). Consulta de autuações ambientais e embargos. Disponível em: <https://servicos.ibama.gov.br/ctf/publi-

co/areasembargadas/ConsultaPublicaAreasEmbargadas.php>. Acesso em $19 / 04 / 2020$.

JASSO, Gerardo M. Apuntes teóricos brasileños a la historia ambiental: un passo impostergable en la construción de una historia ambiental latino-americana y caribeña. Revista de El Colegio de San Luis, ano IX, nº 18, pp. 327-353, 2019.

KOHLHEPP, Gerd. Pioneiros brasileiros nas pesquisas geográficas de desenvolvimento regional: Orlando Valverde e Hilgard O’Reilly Sternberg. Revista Brasileira de Desenvolvimento Regional, v. 3, nº 1, pp. 27-54, 2015.

KOHLHEPP, Gerd. O Programa Piloto Internacional de Proteção das Florestas Tropicais no Brasil (1993-2008): As primeiras estratégias da política ambiental e de desenvolvimento regional para a Amazônia Brasileira. Revista Nera, v. 21, nº 42, pp. 308330, 2018.

KOHLHEPP, Gerd. Entrevista. AMBIENTES: Revista de Geografia e Ecologia Política, v. 2, $n^{\circ} 2$, pp. 398-437, 2020.

MALHEIRO, Bruno C. Colonialismo Interno e Estado de Exceção: a "emergência" da Amazônia dos Grandes Projetos, Caderno de Geografia, v. 30, n 60, pp. 74-98, 2020.

MARGULIS, Sérgio; GUSMÃO, Paulo P. de. Problemas da Gestão Ambiental na Vida Real: a experiência do Rio de Janeiro. IPEA, Texto Para Discussão n 461, fev./1997.

MOURA, Adriana M. de. Trajetória da política ambiental federal no Brasil. In: MOURA, Adriana M. de (org.). Governança Ambiental no Brasil: instituições, atores e políticas públicas. Brasília: Ipea, 2016, p. 13-44.

MOURA, Adriana M. de; FONSECA, Igor F. da. Conselho Nacional de Meio Ambiente: Análise e recomendações de aperfeiçoamento. In: MOURA, Adriana M. de (org.). Governança Ambiental no Brasil: instituições, atores e políticas públicas. Brasília: Ipea, 2016, p. 59-90.

NOGUEIRA-NETO, Paulo. Diário de uma trajetória ambientalista. São Paulo: Empresa das Artes, 2010.

PORTO-GONÇALVES, Carlos Walter. Amazônia, Amazônias. São Paulo: Contexto, 2001. 
PORTO-GONÇALVES, Carlos W. Amazônia: ncruzilhada civilizatória. Tensões territoriais em curso. Obrajes: IPDRS/CIDES/UMSA, 2018.

ROCCO, Rogerio. Legislação Brasileira do Meio Ambiente. Rio de Janeiro: DP\&A, 2002.

SOUZA, Celina. Políticas públicas: uma revisão da literatura. Sociologias, $n^{\circ} 16$, pp. 20-45, 2006.

SOUZA, Marcelo Lopes de. Ambientes e territórios: Uma introdução à ecologia política. Rio de Janeiro: Bertrand Brasil, 2019.

THEODORO, Suzi H.; PIRES, Armando C.; SAYAGO, Doris A. V.; NASCIMENTO, Elimar P.; VARGAS, Glória; WERHMANN, Magda E. F.; BURSZTYN, Marcel; MOURÃO, Laís; DRUMMOND, José A. Primeira parte - uma crise anunciada. In: THEODORO, Suzi Huff (org.). Mediação de conflitos socioambientais. Rio de Janeiro: Garamond, 2005, p. 23-71.

VALVERDE, Orlando. A organização do espaço na faixa da Transamazônica. Rio de Janeiro: IBGE, 1979.

VALVERDE, Orlando; FREITAS, Tácito Lívio Reis de Freitas. O Problema Florestal na Amazônia Brasileira. Petrópolis: Vozes, 1980.

Paulo Pereira de Gusmão é Professor no Programa de Pós-graduação em Geografia da Universidade Federal do Rio de Janeiro (UFRJ).E-mail: ppg.gusmao@gmail.com

Bianca Borges Medeiros Pavão é Doutora em Políticas Públicas e Sustentabilidade pelo Centro de Desenvolvimento Sustentável da Universidade de Brasília (UnB) e pesquisadora na FGV Direito Rio. E-mail: medeiros.biancab@gmail.com

Artigo enviado em 18/09/2020 e aprovado em 06/12/2020. 